\title{
Synthesis of Lapachol-Based Glycosides and Glycosyl Triazoles with Antiproliferative Activity Against Several Cancer Cell Lines
}

Flaviano Melo Ottoni

UFMG: Universidade Federal de Minas Gerais

Lucas Bonfim Marques

UFMG: Universidade Federal de Minas Gerais

Juliana Martins Ribeiro

UFMG: Universidade Federal de Minas Gerais

Lucas Lopardi Franco

UFMG: Universidade Federal de Minas Gerais

José Dias Souza Filho

UFMG: Universidade Federal de Minas Gerais

Rodrigo Maia Pádua

UFMG: Universidade Federal de Minas Gerais

Elaine Maria Souza-Fagundes

UFMG: Universidade Federal de Minas Gerais

Ricardo José Alves ( $\nabla$ ricardodylan@farmacia.ufmg.br)

Federal University of Minas Gerais State https://orcid.org/0000-0002-1666-4421

\section{Research Article}

Keywords: Lapachol, glycosides, glycosyl triazoles, DNA fragmentation, clonogenicity, antiproliferative activity

Posted Date: September 27th, 2021

DOI: https://doi.org/10.21203/rs.3.rs-916974/v1

License: (c) (i) This work is licensed under a Creative Commons Attribution 4.0 International License. Read Full License 


\section{Synthesis of lapachol-based glycosides and glycosyl triazoles with antiproliferative activity against several cancer cell lines}

Flaviano M. Ottoni ${ }^{1}$. Lucas B. Marques ${ }^{2}$. Juliana M. Ribeiro ${ }^{2}$. Lucas L. Franco ${ }^{3}$. José D. S. Filho ${ }^{4}$. Rodrigo Maia de

Pádua $^{1}$. Elaine M. Souza-Fagundes ${ }^{2}$. Ricardo J. Alves ${ }^{1}$

$\square$ Ricardo J. Alves

ricardodylan@farmacia.ufmg.br

${ }^{1}$ Departamento de Produtos Farmacêuticos, Faculdade de Farmácia, Universidade Federal de Minas Gerais (UFMG), Avenida Antônio Carlos, 6627, Belo Horizonte, MG 31.270-901, Brazil.

${ }^{2}$ Departamento de Biofísica e Fisiologia, Instituto de Ciências Biológicas, Universidade Federal de Minas Gerais (UFMG), Avenida Antônio Carlos, 6627, Belo Horizonte, MG 31.270-901, Brazil.

${ }^{3}$ Laboratório de Pesquisa em Química Farmacêutica (LQFar), Faculdade de Ciências Farmacêuticas, Universidade Federal de Alfenas (UNIFAL), Alfenas, MG 37130-001, Brazil

${ }^{4}$ Departamento de Química, Instituto de Ciências Exatas, Universidade Federal de Minas Gerais (UFMG), Avenida Antônio Carlos, 6627, Belo Horizonte, MG 31.270-901, Brazil.

ABSTRACT Lapachol (1), a natural naphthoquinone, presents several biological activities including antitumor activity, used as anticancer coadjuvant whose use was abandoned because of adverse effects. Herein, we reported the synthesis and cytotoxicity evaluation against cancer cell lines of a series of $O$ glycosides and glycosyl triazoles derived from lapachol. In addition to the determination of $\mathrm{IC}_{50}$, the DNA fragmentation and clonogenicity were also evaluated. The glycoside derived from D-glucose (5) was far more active than lapachol (1) and more active in tumor cell lines HL60, Jurkat, THP-1 and MDA-MB-231 than to the non-tumoral PBMC cell line, indicating an improvement in activity and selectivity as compared with lapachol (1). Compound 5 and the glycosides derived from D-galactose (14), D- $N$-acetylglucosamine (15) and L-fucose (16) showed good results in the DNA fragmentation and clonogenicity assays in the studies of subdiploid DNA content, indicating a pro-apoptotic potential and a good antiproliferative activity of these glycosides.

\footnotetext{
${ }^{1 *}$ Corresponding author. Tel.: +55 (31) 3409-6955; fax: +55-(31)-3409-6935; e-mail ricardodylan@farmacia.ufmg.br
} 


\section{Graphical abstract}

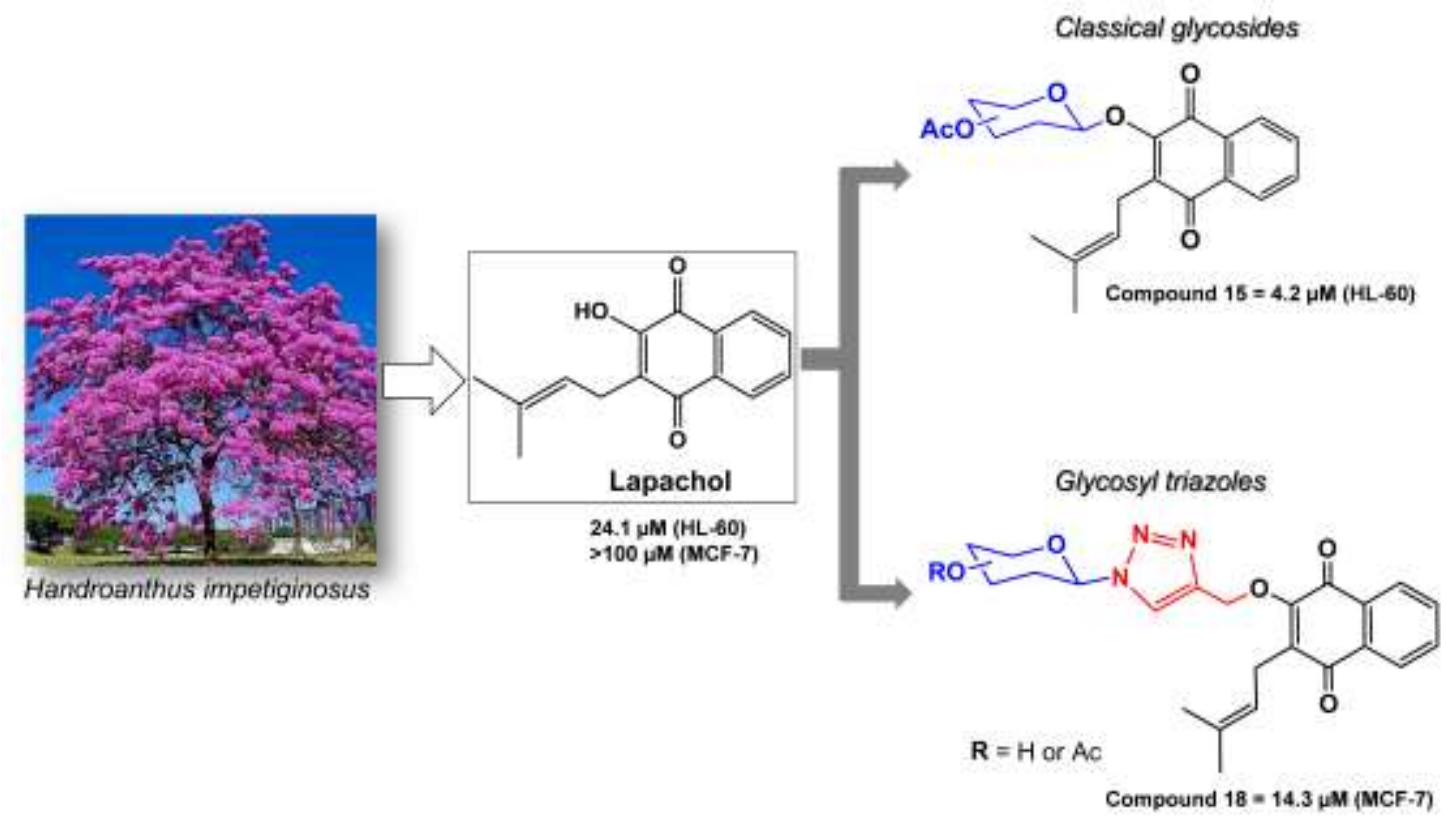

\section{Keywords}

Lapachol, glycosides, glycosyl triazoles, DNA fragmentation, clonogenicity, antiproliferative activity

\section{Introduction}

Cancer is one of the principal causes of death worldwide and its incidence is expected to increase in the next years. According to WHO, about 30 million cases of cancer are expected to occur until 2040, with almost 50\% taking place in developing countries [1]. Despite the great efforts in prevention and treatment of cancer there is a continuous need for new options. The lack of selective action towards the cancer cells of most current existing anticancer drugs results in toxicity to host tissues. Thus, the search for new potent and safer drugs of synthetic and natural origin is being pursued by several groups around the world.

Natural (paclitaxel, doxorubicin, vincristine) and semi synthetic compounds (etoposide and docetaxel) are among the most important anticancer drugs (Fig. 1). Etoposide and docetaxel are good examples of how synthetic modification can contribute to improve the activity of bioactive natural compounds [2, 3]. 

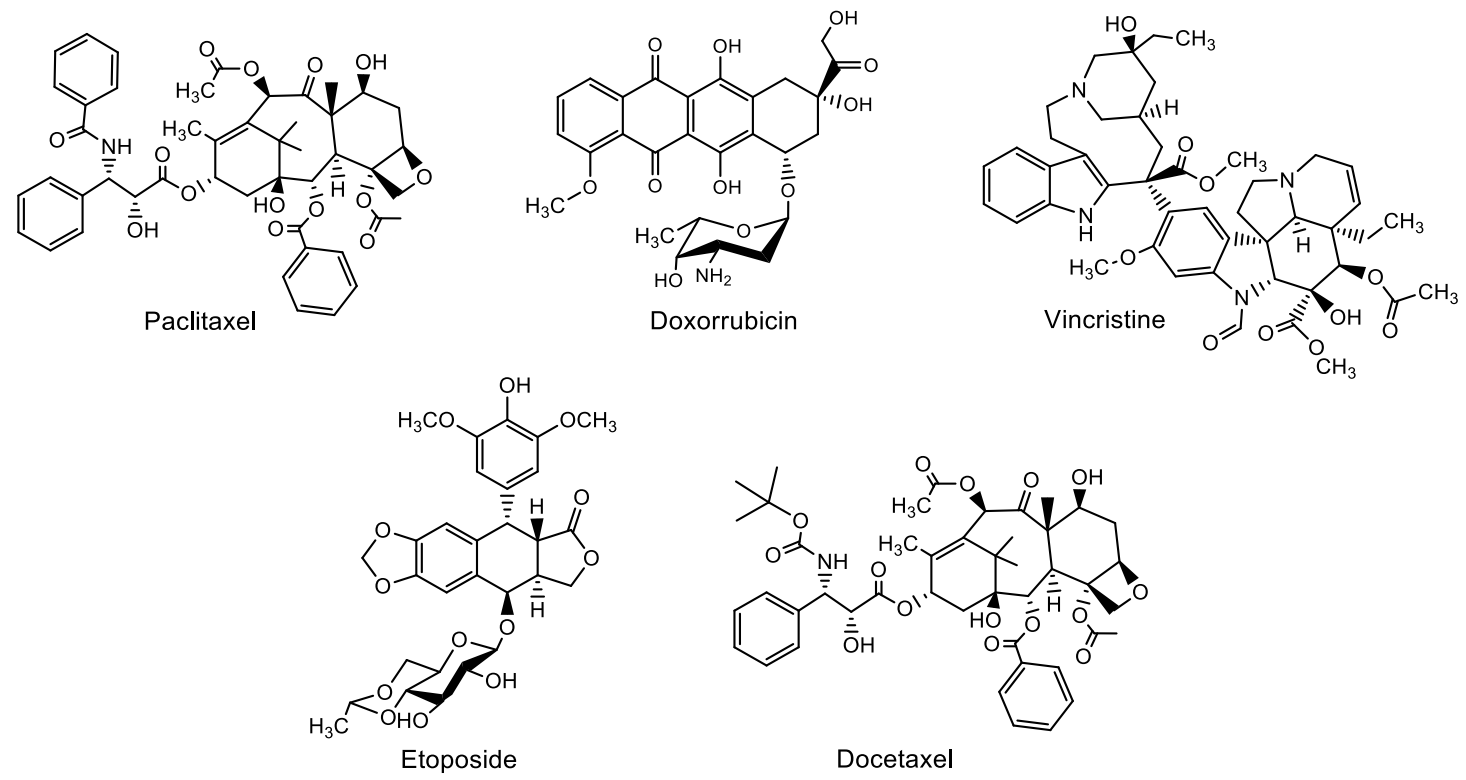

Fig. 1. Anticancer agents of natural and semi synthetic origin.

Lapachol (1), 2-hydroxy-3-(3-methyl-2-butenyl)-1,4-naphthalenedione is a natural 1,4-naphthoquinone isolated from plants of the Bignoniaceae family, mainly Handroanthus impetiginosus. It presents several biological activities including antitumor activity $[4,5]$. This compound has been used as coadjuvant in the chemotherapy of certain tumors but its use was abandoned because of adverse effects, mainly related to blood clotting.[5, 6] Some synthetic routes were established to get lapachol (1), firstly by Fieser [7], being obtained in low yields. Recently, lapachol was synthetized from lawsone in better yields [8]. Several derivatives of $\mathbf{1}$ were prepared with antifungal, antibacterial, antiviral and antitumor activity [5]. Eyong et al. described the synthesis of atovaquone, which was approved for treatment of pneumonia (Pneumocystis pneumonia), toxoplasmosis and malaria [4, 9]. Atovaquone is a naphthoquinone as well as lapachol and studies carried out in the last years have shown that atovaquone has a potent antitumor activity [10]. The chemical structure of $\mathbf{I}$ and some of its derivatives with antitumor activity are shown below (Fig. 2). 


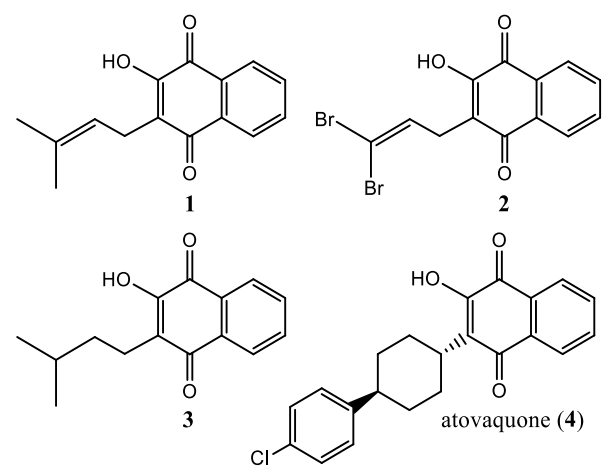

Fig. 2. Chemical structure of $\mathbf{1}$ and some derivatives showing antitumor activity [4, 5].

The quinones are able to inhibit the mitochondrial oxidation and phosphorylation, as well to inhibit the enzyme succinate oxidase [11] which plays an important role in the citric acid cycle and the electron transport chain. Other mechanisms seem to be related to the intercalation of the naphthoquinones between the DNA base pairs [5] and inhibition of topoisomerases [12]. The main mechanism of action is related to the formation of reactive oxygen species (ROS), through semiquinone radicals. Both cause damage to cell macro molecules and consequently cell death [12].

The major problem for the clinical use of $\mathbf{1}$ is its low bioavailability, due to low water solubility, which implicated in the use of large doses for attaining plasmatic levels, causing severe side effects. The first attempt to enhance water solubility of lapachol was reported by Linardi and co-workers who described the synthesis of the $\beta$-D-glucoside of $\mathbf{1}$ (compound $\mathbf{6}$ ) and the corresponding peracetylated derivative $\mathbf{5}$ (Fig. 3) [13]. These two compounds were evaluated in vivo in mice bearing P-388 lymphocytic leukemia. The peracetylated glucoside $\mathbf{5}$ was active, enhancing the lifespan of mice by $80 \%$, while the deacetylated derivative was inactive. According to the authors, the peracetylated glucoside was possibly acting as prodrug that could be absorbed by the cancer cells due to its lipophilic character. The unprotected derivative 6, being more hydrophilic, was possibly unable to cross the cell membranes being, therefore, inactive.[13]
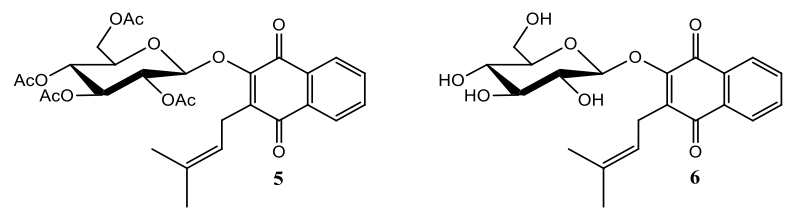

Fig. 3. Chemical structures of the peracetylated $\beta$-D-glucoside (5) and $\beta$-D-glucoside (6) of lapachol. 
Several anticancer drugs possess a carbohydrate moiety in their structures, as shown in Fig. 1 for etoposide and doxorubicin. The work of Linardi and co-workers [13] showed that the attachment of a glucosyl moiety to lapachol can be a good approach to obtain new anticancer compounds. Glycosidic derivatives of lawsone, another naphthoquinone, has been obtained and assayed for antitumor activity. The glycosides were cytotoxic against HL-60 (acute promyelocytic leukemia), SKBR-3, MCF-7 and MDA-MB-231 (breast cancer) cells indicating that the variation of the carbohydrate moiety and the anomer type ( $\alpha$ or $\beta$-glycoside) influence the cytotoxicity $[14,15]$. Some these lawsone glycosides with antitumor activity are shown in Fig. 4.

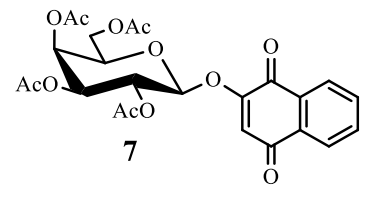

$\mathrm{IC}_{50}: 6.9 \mu \mathrm{M}(\mathrm{HL}-60)$

$\mathrm{IC}_{50}: 8.9 \mu \mathrm{M}(\mathrm{SKBR}-3)$

$\mathrm{IC}_{50}: 13.6 \mu \mathrm{M}(\mathrm{MCF}-7)$

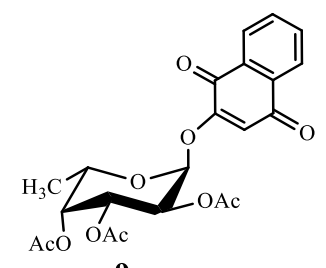

9

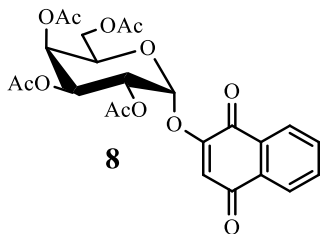

$\mathrm{IC}_{50}: 3.4 \mu \mathrm{M}(\mathrm{HL}-60)$

$\mathrm{IC}_{50}: 2.5 \mu \mathrm{M}(\mathrm{SKBR}-3)$

$\mathrm{IC}_{50}: 4.6 \mu \mathrm{M}(\mathrm{MCF}-7)$

$$
\begin{array}{ll}
\mathrm{IC}_{50}: 9.5 \mu \mathrm{M}(\mathrm{SKBR}-3) & \mathrm{IC}_{50}: 2.4 \mu \mathrm{M}(\mathrm{SKBR}-3) \\
\mathrm{IC}_{50}: 11.0 \mu \mathrm{M}(\mathrm{MCF}-7) & \mathrm{IC}_{50}: 5.0 \mu \mathrm{M}(\mathrm{MCF}-7) \\
\mathrm{IC}_{50}: 18.2 \mu \mathrm{M}(\mathrm{MDA}-\mathrm{MB}-231) & \mathrm{IC}_{50}: 8.6 \mu \mathrm{M}(\mathrm{MDA}-\mathrm{MB}-231)
\end{array}
$$

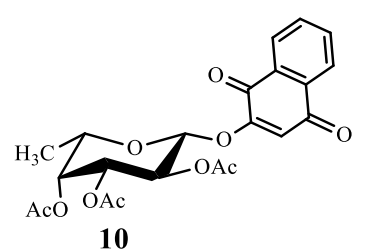

Fig. 4. Chemical structures of synthetic glycosides derived from lawsone active against cancer cells.

Besides classical glycosides, obtained by direct glycosylation, one strategy widely used to link a carbohydrate moiety to a natural or synthetic compound is the $\mathrm{Cu}(\mathrm{I})$-catalyzed cycloaddition reaction between an alkyne derivative of the compound with a glycosyl azide, to get glycosyl triazoles [16]. Based on this, several glycosyl triazoles derived from naphthoquinones with antitumor activity are described in the literature (Fig. 5) [17-19]. 


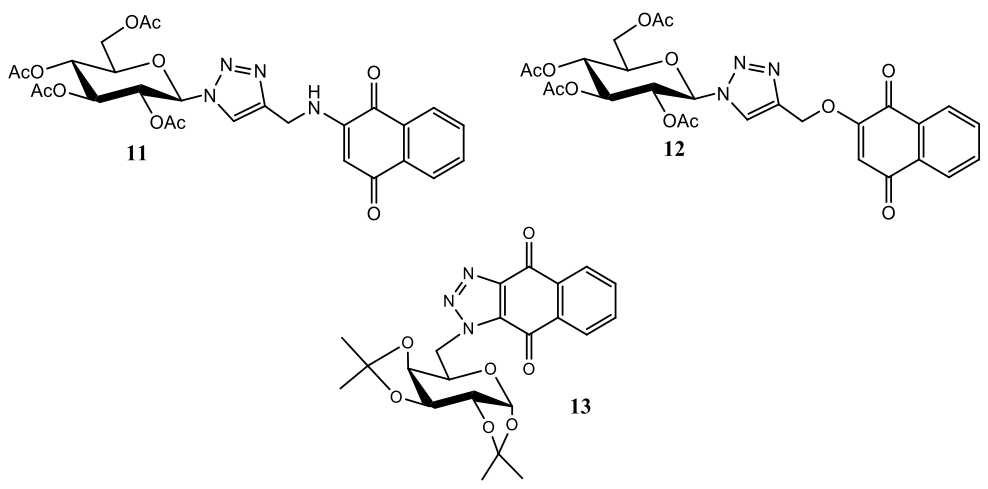

Fig. 5. Chemical structures of synthetic glycosyl triazoles derived from naphthoquinones.

Recently we described the synthesis and cytotoxic evaluation against HL-60 human leukemia cells of lapachol glycosides 5 and 15. These compounds showed low $\mathrm{IC}_{50}$ values, circa $5.0 \mu \mathrm{M}$. The mechanism of cytotoxic seems to involve the activation apoptosis signaling pathways, such as the DNA fragmentation, chromatin condensation and decrease of the mitochondrial transmembrane potential [20].

In the present work we describe the synthesis and cytotoxicity evaluation against cancer cell lines of a series of $O$-glycosides and glycosyl triazoles derived from lapachol. The structures of the synthesized compounds are shown in Fig. 6.
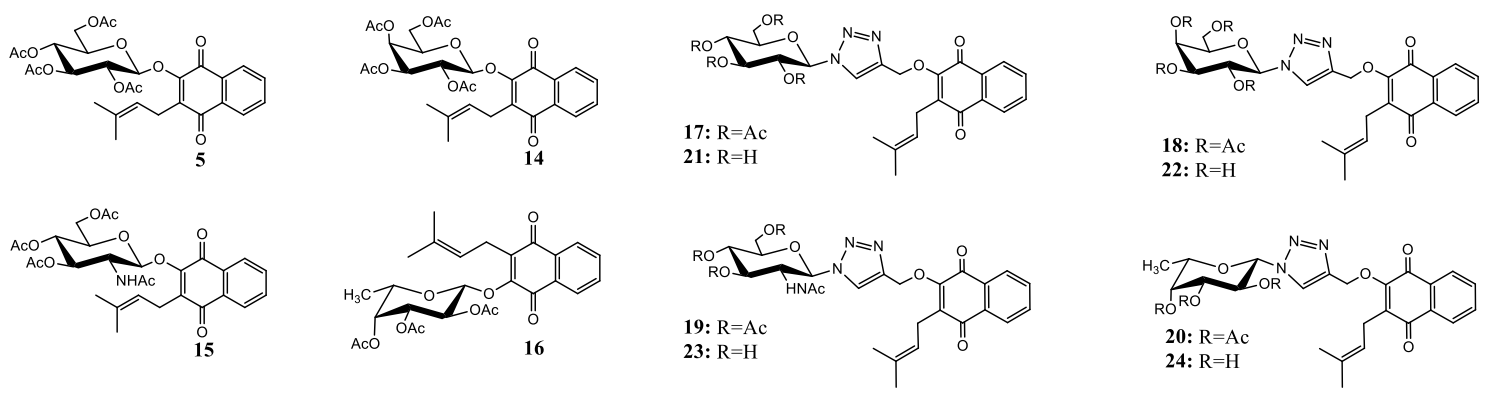

Fig. 6. Chemical structures of the glycosyl triazoles derived from lapachol synthesized in this work.

The presence and orientation of groups $(\mathrm{OH}$ and $\mathrm{NHAc})$ that can modulate the physico-chemical properties of the compounds was considered, taking into account that the parent carbohydrates have different solubility and that the $O$-acetyl groups confer lipophilic properties to the peracetylated derivatives. We also considered the presence of specific carbohydrate transporters in the cell surface [21], that should facilitate the transport of the deacetylated glycosides across the cancer cell membrane. 


\section{Results and discussion}

\subsection{Chemistry}

The classic glycosides of lapachol (1) were obtained by its reaction with the glycosyl halides [22-24] under phase transfer catalysis (PTC) conditions: $10 \% \mathrm{w} / \mathrm{v}$ sodium carbonate aqueous solution, dichloromethane and tetra- $n$-butyl bromide (TBAB) as phase transfer catalyst [25-27]. As glycosyl halides were used peracetylated glycosyl bromides from D-glucose, D-galactose [23] and L-fucose [24] and the peracetylated D- $N$-acetylglucosaminyl chloride [22]. The compounds were synthesized according to the synthetic scheme shown below (Scheme 1).
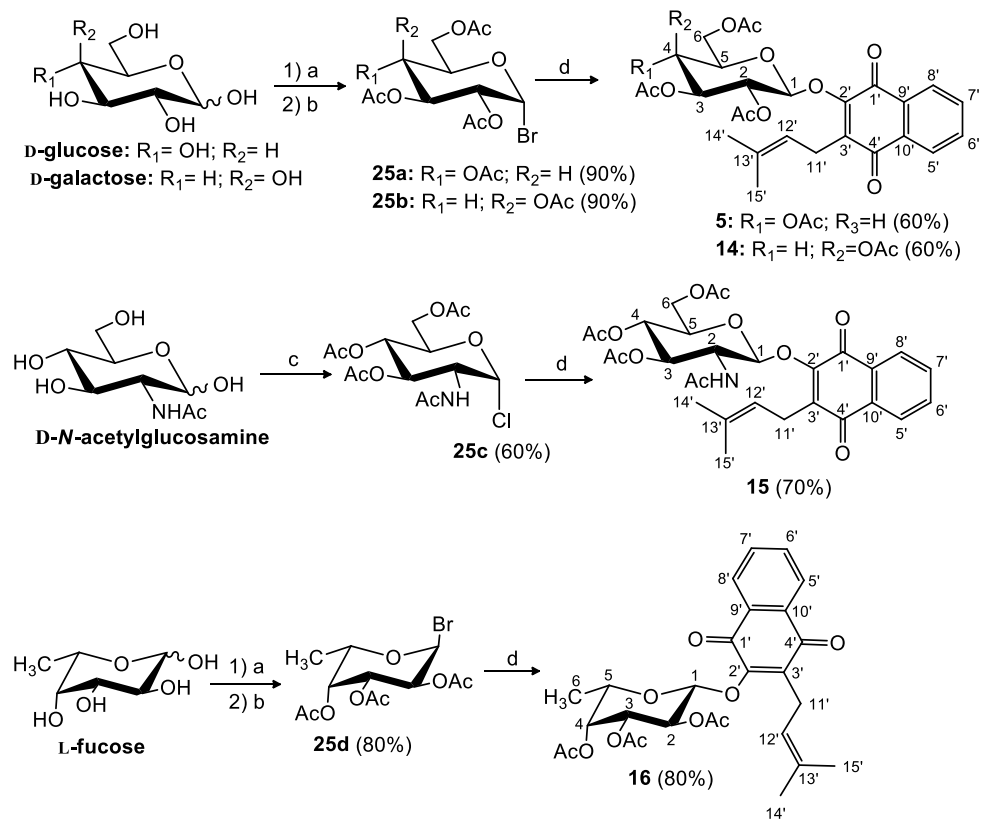

Scheme 1. Reagents and conditions (a) $\mathrm{Ac} 2 \mathrm{O}, \mathrm{AcONa}, 100{ }^{\circ} \mathrm{C}, 5 \mathrm{~h},\left[90 \%\right.$ ]; (b) $\mathrm{HBr} / \mathrm{AcOH}, \mathrm{CH}_{2} \mathrm{Cl}_{2}$, r.t, 6 h, [90-95\%]; (c) $\mathrm{CH}_{3} \mathrm{COCl}$, r.t, 48 h, [50\%]; (d) Lapachol, $\mathrm{CH}_{2} \mathrm{Cl}_{2}, \mathrm{Na}_{2} \mathrm{CO}_{3} 10 \%$ p/v (1:1), n- $\mathrm{Bu}_{4} \mathrm{NBr}$, r.t, 8 h, [60-80\%] .r.t. $=$ room temperature; yields $=[$ ].

The peracetylated glycosides form D-glucose, D-galactose and L-fucose were prepared using sodium acetate $(\mathrm{AcONa})$ and acetic anhydride $\left(\mathrm{Ac}_{2} \mathrm{O}\right)$ as solvent at $100{ }^{\circ} \mathrm{C}$. The treatment of peracetylated carbohydrates with $\mathrm{HBr} / \mathrm{AcOH}$ solution at room temperature furnished the corresponding glycosyl bromide $[23,24]$. The peracetylated glycosyl halide derived from $\mathrm{D}-\mathrm{N}$-acetylglucosamine was obtained reacting D$\mathrm{N}$-acetylglucosamine with acetyl chloride at room temperature for $48 \mathrm{~h}$ [22]. Finally, in the glycosylation step the reaction of lapachol (1) with each of the glycosyl halides (25a-d) afforded the corresponding peracetylated lapachol glycosides 5 and 14-16 in 60-80\% yields. 
The glycosyl triazoles of 1 were synthesized using "click" chemistry [28-30] namely, the reaction of the 2-O-propargyllapachol (28) with glycosyl azides (26 and 27) [31-34], prepared according to the synthetic scheme shown below (Scheme 1).

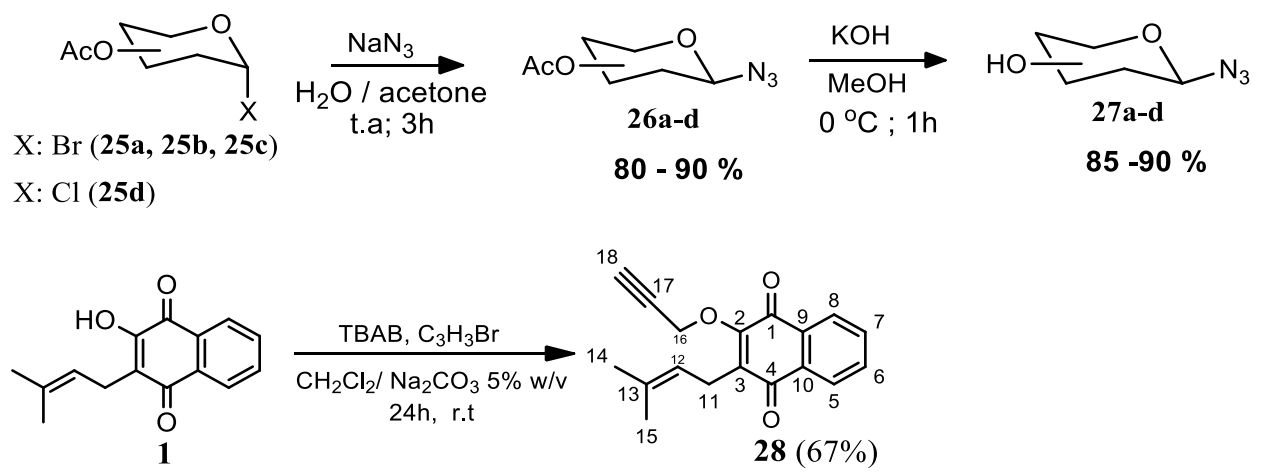

Scheme 2. Reaction conditions for the obtention of 2-O-propargyllapachol and the glycosyl azides.

Treatment of lapachol with propargyl bromide under phase-transfer conditions [25-27] furnished the corresponding 2-O-propargyllapachol (28) in $67 \%$ yield. The glycosyl azides 26a-d were obtained from the corresponding peracetylated glycosyl halides (25a-d) according to literature procedures, namely, reaction with $\mathrm{NaN}_{3}$ in acetone/ $\mathrm{H}_{2} \mathrm{O}$ at room temperature [35]. Deacetylation of 26a-d under standard conditions $\left(\mathrm{KOH} / \mathrm{MeOH}\right.$ at $\left.0{ }^{\circ} \mathrm{C}\right)[33,34]$ furnished the corresponding unprotected glycosyl azides 27a-d in good yields (Scheme 2).

Finally, $\mathrm{Cu}(\mathrm{I})$-catalyzed cycloaddition reaction of $\mathbf{2 8}$ with each of the glycosyl azides (26a-d and 27a-d) afforded the corresponding peracetylated (17-20) and deacetylated (21-24) glycosyl triazoles of lapachol yields ranging from $47 \%$ to $85 \%$ (Scheme 3 ). 

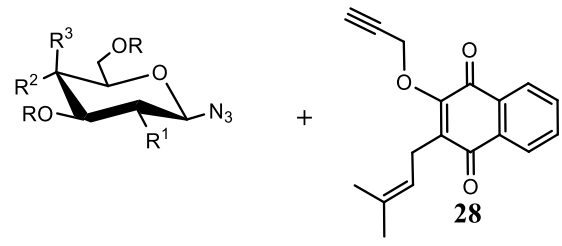

26a: $R^{1}=R^{2}=$ OAc; $R^{3}=H ; R=A c(85 \%)$

26b: $R^{1}=R^{3}=O A c ; R^{2}=H ; R=A c(90 \%)$

26c: $R^{1}=N H A c ; R^{2}=O A c ; R^{3}=H ; R=A c(85 \%)$

27a: $R^{1}=R^{2}=O H ; R^{3}=H ; R=H(85 \%)$

27b: $\mathrm{R}^{1}=\mathrm{R}^{3}=\mathrm{OH} ; \mathrm{R}^{2}=\mathrm{H} ; \mathrm{R}=\mathrm{H}(90 \%)$

27c: $R^{1}=$ NHAc; $R^{2}=O H ; R^{3}=H ; R=H(85 \%)$

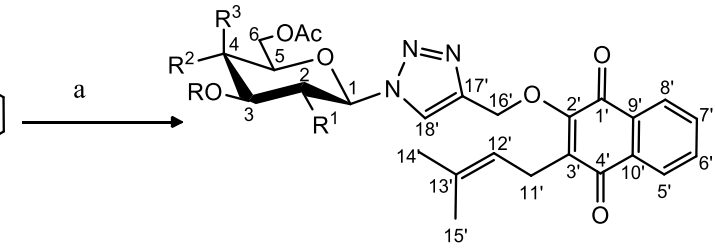

17: $\mathrm{R}^{1}=\mathrm{R}^{2}=$ OAc; $\mathrm{R}^{3}=\mathrm{H} ; \mathrm{R}=\mathrm{Ac}(68 \%)$

18: $\mathrm{R}^{1}=\mathrm{R}^{3}=\mathrm{OAc} ; \mathrm{R}^{2}=\mathrm{H} ; \mathrm{R}=\mathrm{Ac}(57 \%)$

19: $R^{1}=$ NHAc; $R^{2}=$ OAc; $R^{3}=H ; R=A c(68 \%)$

21: $\mathrm{R}^{1}=\mathrm{R}^{2}=\mathrm{OH} ; \mathrm{R}^{3}=\mathrm{H} ; \mathrm{R}=\mathrm{H}(59 \%)$

22: $\mathrm{R}^{1}=\mathrm{R}^{3}=\mathrm{OH} ; \mathrm{R}^{2}=\mathrm{H} ; \mathrm{R}=\mathrm{H}(51 \%)$

23: $\mathrm{R}^{1}=\mathrm{NHAc} ; \mathrm{R}^{2}=\mathrm{OH} ; \mathrm{R}^{3}=\mathrm{H} ; \mathrm{R}=\mathrm{H}(55 \%)$

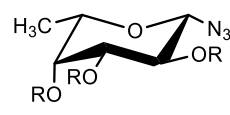

26d: $\mathrm{R}=\mathrm{Ac}(80 \%)$ 27d: $\mathrm{R}=\mathrm{H}(90 \%)$
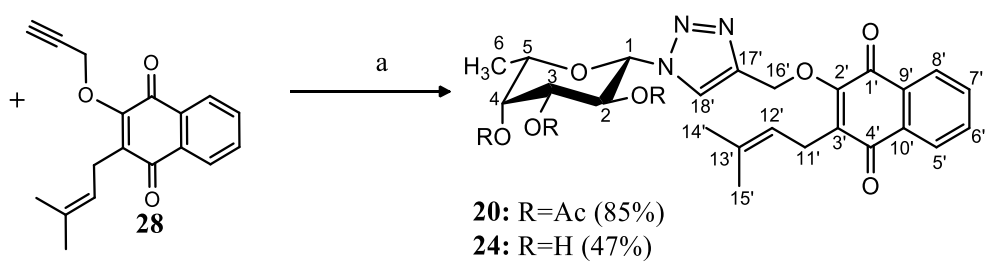

Scheme 3. (a) $\mathrm{Cu}(\mathrm{OAc})_{2} \cdot \mathrm{H}_{2} \mathrm{O}$, sodium ascorbate $60 \%$ mol, THF: $\mathrm{H}_{2} \mathrm{O}$ (1:1), r.t, 2-5h, [47-85\%]. r.t. $=$ room temperature; yields $=[$ ].

The compounds were characterized by IR, NMR and ESI-MS spectroscopy. The infrared spectra of the peracetylated glycosides of lapachol $\mathbf{5}$ and $\mathbf{1 4 - 1 6}$ showed bands at $3039-2858 \mathrm{~cm}^{-1}$ (C-H alkane and aromatic), $1748-1742 \mathrm{~cm}^{-1}\left(\mathrm{C}=\mathrm{O}\right.$, ester) and $1224-1213 \mathrm{~cm}^{-1}$ (C-O, ester). In the infrared spectrum of compound 16 one observes bands at $3308 \mathrm{~cm}^{-1}$ (stretching $\left.\mathrm{N}-\mathrm{H}\right), 1666 \mathrm{~cm}^{-1}\left(\mathrm{C}=\mathrm{O}\right.$ amide) and $1539 \mathrm{~cm}^{-1}$ (bending N-H) correspondent to acetamido group in $\mathrm{C}-2$. The ${ }^{1} \mathrm{H}$ NMR spectra of these compounds showed signals at $\delta_{\mathrm{H}} 1.65-1.83 \mathrm{ppm}$ (methyl groups at C-14' and C-15' of the lapachol moiety), $\delta_{\mathrm{H}} 1.94-2.20 \mathrm{ppm}$ $\left(\mathrm{C}_{3} \mathrm{C}=\mathrm{O}\right), \delta_{\mathrm{H}} 3.30-3.45 \mathrm{ppm}$ (methylenic hydrogens at $\mathrm{C}-11$ ' of the lapachol), $\delta_{\mathrm{H}} 3.66-5.83 \mathrm{ppm}$ (pyranosidic protons), $\delta_{\mathrm{H}} 5.09-5.13 \mathrm{ppm}$ (olefinic hydrogens $\mathrm{H}-12$ 'of the isoprenyl side chain) and 7.69$8.10 \mathrm{ppm}$ (aromatic hydrogens of lapachol). In the ${ }^{1} \mathrm{H}$ NMR spectrum of compound 15 (D- $N$ acetylglucosamine derivative) the signal corresponding at $\mathrm{N}-\mathrm{H}$ resonates at $\delta_{\mathrm{H}} 6.35 \mathrm{ppm}(d, J=8.8 \mathrm{~Hz} ; 1 \mathrm{H}$, $\mathrm{N}-\mathrm{H}$ acetamide) and the signal of $\mathrm{H}-6$ of the compound $\mathbf{1 6}$ (L-fucose derivative) is recorded at as a duplet at $\delta_{\mathrm{H}} 1.14 \mathrm{ppm}(d, J=6.4 \mathrm{~Hz} ; 1 \mathrm{H}, \mathrm{H}-6 \mathrm{~L}$-fucose $)$. All lapachol glycosides correspond to $\beta$ anomer as confirmed by ${ }^{1} \mathrm{H}$ NMR spectrometry, wherein one observes signals at $\delta_{\mathrm{H}} 5.36$ and $\delta_{\mathrm{H}} 5.84$, corresponding at H-1 (anomeric hydrogen), with $J$-coupling values around $8.0 \mathrm{~Hz}$. According to Karplus's rule coupling between vicinal hydrogens with $J$-coupling values ranging 8.0 to $10.0 \mathrm{~Hz}$ correspond trans-diaxial coupling compatible with $\beta$-type glycosides [36]. These structural features were confirmed by the ${ }^{13} \mathrm{C}$ NMR spectra of these compounds, which showed signals at $\delta_{\mathrm{C}} 17.7-18.3 \mathrm{ppm}\left(\mathrm{CH}_{3}, \mathrm{C}-14^{\prime}\right), \delta_{\mathrm{C}} 20.3-21.1 \mathrm{ppm}\left(\mathrm{CH}_{3}\right.$, 
ester), $\delta_{\mathrm{C}} 23.2-23.7 \mathrm{ppm}\left(\mathrm{CH}_{2}, \mathrm{C}-11^{\prime}\right), \delta_{\mathrm{C}} 25.5-26.1 \mathrm{ppm}\left(\mathrm{CH}_{3}, \mathrm{C}-15^{\prime}\right), \delta_{\mathrm{C}} 54.3-73.3 \mathrm{ppm}(\mathrm{CH}, \mathrm{C}-2$ to C-5), $\delta_{\mathrm{C}}$ 99.3-100.4 ppm (CH, C-1'), $\delta_{\mathrm{C}} 119.2-119.6 \mathrm{ppm}\left(\mathrm{CH}, \mathrm{C}-12^{\prime}\right), \delta_{\mathrm{C}} 125.8-134.5 \mathrm{ppm}\left(\mathrm{CH}, \mathrm{C}-5\right.$ ' at C-10'), $\delta_{\mathrm{C}}$ $137.5-139.1 \mathrm{ppm}\left(\mathrm{CH}, \mathrm{C}-3^{\prime}\right), \delta_{\mathrm{C}} 152.6-153.2 \mathrm{ppm}\left(\mathrm{CH}, \mathrm{C}-2^{\prime}\right), \delta_{\mathrm{C}} 169.5-171.0 \mathrm{ppm}\left(\mathrm{C}=\mathrm{O}\right.$, ester) and, $\delta_{\mathrm{C}}$ 180.4-185.2 ppm ( $\mathrm{C}=\mathrm{O}$, quinone). In the ${ }^{13} \mathrm{C}$ NMR spectrum of $\mathbf{1 5}$ one observes signals at $\delta_{\mathrm{C}} 23.4 \mathrm{ppm}$ $\left(\mathrm{CH}_{3}\right.$, amide $)$ and at $\delta_{\mathrm{C}} 168.3 \mathrm{ppm}(\mathrm{C}=\mathrm{O}$, amide $)$. For compound 16 one observes a signal at $\delta_{\mathrm{C}} 15.6 \mathrm{ppm}$ $\left(\mathrm{CH}_{3}, \mathrm{C}-6\right)$. The $\beta$-configuration at the anomeric carbon of glycosides 5 and 14-16 was confirmed by the resonance signals at $\delta_{\mathrm{C}} 99.3-100.4\left(\mathrm{CH}, \mathrm{C}-1^{\prime}\right)$.

The infrared spectrum of the 2-O-propargyllapachol (28) showed absorption bands at $3355-3279 \mathrm{~cm}^{-1}(\mathrm{C}-$ $\mathrm{H}$ alkyne), 2964-2953 cm-1 (C-H sp $), 2124 \mathrm{~cm}^{-1}$ (C-C alkyne), 1660-1640 cm $\mathrm{cm}^{-1}$ (C=C olefin), 1610-1593 $\mathrm{cm}^{-1}\left(\mathrm{C}=\mathrm{C}\right.$ aromatic), 1186 and $1047 \mathrm{~cm}^{-1}(\mathrm{C}-\mathrm{O})$. The ${ }^{1} \mathrm{H}$ NMR spectrum of 28 showed signals assigned to the alkyne terminal hydrogen $\mathrm{H}-18$ at $\delta_{\mathrm{H}} 2.51 \mathrm{ppm}(d, J=2.0 \mathrm{~Hz})$ and the methylene hydrogens $\mathrm{H}-16$ at $\delta_{\mathrm{H}}$ $5.14 \mathrm{ppm}(d, J=2.4 \mathrm{~Hz})$, both as a doublet. In the ${ }^{13} \mathrm{C}$ NMR spectrum of 28 one observes signals corresponding to the propargyl group at $\delta_{\mathrm{C}} 60.3 \mathrm{ppm}$ (methylene carbon C-16), $\delta_{\mathrm{C}} 76.4 \mathrm{ppm}$ and $\delta_{\mathrm{C}} 78.4$ ppm (alkyne carbons $\mathrm{C}-17$ and C-18).

The infrared spectra of the peracetylated glycosyl triazoles of lapachol 17-20 were similar to those of the lapachol glycosides 5 and 14-16 (N-H, C-H, C=O, C=C and C-O stretching and $\mathrm{N}-\mathrm{H}$ bend). The ${ }^{1} \mathrm{H}$ NMR spectra of the glycosyl triazoles 17-20 showed a singlet at $\delta_{\mathrm{H}} 7.98-8.55 \mathrm{ppm}$ corresponding to the hydrogen of the triazole ring (H-18). As expected, all glycosyl triazoles 17-24 are of $\beta$ configuration, the same as the glycosyl azides, which were obtained by $\mathrm{S}_{\mathrm{N}} 2$ type nucleophilic substitution from glycosyl halides, which present $\alpha$ configuration already stabilized by the anomeric effect [37]. For example, in the ${ }^{1} \mathrm{H}$ NMR spectrum of compound 17 one observes a signal at $\delta_{\mathrm{H}} 6.37$ corresponding to $\mathrm{H}-1$, with $J$-coupling value $\left(J^{3}\right)$ around $8.0 \mathrm{~Hz}$. As discussed previously these vicinal coupling constant values correspond to trans-diaxial coupling and confirm the $\beta$ configuration of glycosyl triazoles of lapachol (17-24) [36].

In the ${ }^{13} \mathrm{C}$ NMR spectrum of these compounds the anomeric carbon (C-1) signals are observed at 84.3-86.5 ppm and triazole ring carbon $(\mathrm{C}-18)$ at $\delta_{\mathrm{C}} 122.0-133.8 \mathrm{ppm}$. The signal related to the other carbon of the triazole ring (C-17) was observed only in the ${ }^{13} \mathrm{C}$ NMR spectra of compounds 17 (143.7 ppm) and $\mathbf{1 9}$ (143.3 ppm), probably due to the relaxation time of such carbon. 
The infrared spectra of the deprotected glycosyl triazoles 21-24 showed, as expected, absorption bands in the region of $3357-3281 \mathrm{~cm}^{-1}$ due to $\mathrm{OH}$ stretching of the carbohydrate moiety. The ${ }^{1} \mathrm{H}$ NMR and ${ }^{13} \mathrm{C}$ NMR spectra of deprotected glycosyl triazoles 21-24 agree with their chemical structures. The mass spectra of all lapachol derivatives showed molecular weight compatible with the proposed structures (supplementary data available).

\subsection{Biological activities}

\subsubsection{Cytotoxic activity}

Lapachol (1), its classical glycosides 5 and 14-16 and glycosyl triazoles derivatives 17-24 were evaluated for their cytotoxicity against six human cancer cell lines: HL60 (acute promyelocytic leukemia), Jurkat (acute T-cell leukemia), THP-1 (acute monocytic leukemia), MCF-7 (breast adenocarcinoma), MDA-MB231 (triple-negative breast cancer) and HCT-116 (colorectal carcinoma). Cell viability was evaluated using the MTT method to evaluate cell viability as previously described [38-40]. As model of non-tumoral lineages, compounds were tested against human peripheral blood mononuclear cells (PBMC) and viability measured by resazurin assay [41]. Etoposide and lapachol were used as positive controls. Compared with lapachol (1), the majority of its glycosides were more cytotoxic towards one or more tumor cell lines, lapachol (1) being cytotoxic only against HL60, with poor activity when compared to its derivatives. To evaluate the toxicity to non-tumor cells, selected compounds were tested on peripheral blood mononuclear cells (PBMC) cells. The results are shown in Table 1.

Table 1. Cytotoxicity of lapachol (1) and lapachol-based glycosyl triazoles 17-24 against four cancer cell lines and against human peripheral blood mononuclear cells ( $\left.{ }^{\mathrm{a}} \mathrm{IC}_{50}, \mu \mathrm{M}\right)$.

\begin{tabular}{llllllllllllllll}
\hline \multicolumn{10}{c}{$\mathbf{I C}_{\mathbf{5 0}}(\boldsymbol{\mu M})$ and selectivity indexes $(\mathbf{S I})$} \\
\hline & $\mathbf{H L 6 0}$ & SI & Jurkat & SI & THP-1 & SI & $\begin{array}{l}\text { MDA- } \\
\text { MB-231 }\end{array}$ & SI & MCF-7 & SI & $\begin{array}{l}\text { HCT- } \\
\mathbf{1 1 6}\end{array}$ & SI & PBMC \\
\hline $\mathbf{5}$ & $4.4 \pm 0.8$ & 9.8 & $10.2 \pm 3.6$ & 4.2 & $11.5 \pm 2.3$ & 3.7 & $8.2 \pm 2.3$ & 5.2 & $45.8 \pm 10.3$ & 0.9 & $24.9 \pm 5.4$ & 1.7 & $42.9 \pm 6.7$ \\
$\mathbf{1 4}$ & $5.4 \pm 0.8$ & 1 & $10.9 \pm 2.6$ & 0.5 & $12.1 \pm 2.6$ & 0.4 & $10.9 \pm 3.5$ & 0.5 & $31.4 \pm 13.0$ & 0.2 & $23.0 \pm 3.5$ & 0.2 & $5.4 \pm 1.6$ \\
$\mathbf{1 5}$ & $4.2 \pm 0.6$ & 0.2 & $15.6 \pm 4.4$ & 0.05 & $36.5 \pm 0.9$ & 0.02 & $19.8 \pm 8.8$ & 0.04 & $45.1 \pm 4.4$ & 0.02 & $34.7 \pm 3.3$ & 0.02 & $<0.78^{\mathrm{b}}$ \\
$\mathbf{1 6}$ & $6.3 \pm 0.3$ & 0.1 & $10.4 \pm 3.4$ & 0.08 & $14.9 \pm 1.6$ & 0.05 & $14.5 \pm 4.6$ & 0.05 & $33.1 \pm 7.6$ & 0.02 & $24.7 \pm 8.6$ & 0.03 & $<0.78^{\mathrm{b}}$ \\
$\mathbf{1 7}$ & $11.6 \pm 0.3$ & 0.4 & $\mathrm{ND}$ & $\mathrm{ND}$ & $20.8 \pm 0.2$ & 0.3 & ND & ND & ND & ND & ND & ND & $6.1 \pm 2.2$ \\
$\mathbf{1 8}$ & $21.0 \pm 5.2$ & 0.04 & $23.0 \pm 5.4$ & 0.03 & $40.1 \pm 9.4$ & 0.02 & $32.4 \pm 8.5$ & 0.02 & $14.3 \pm 1.5$ & 0.05 & $26.2 \pm 3.3$ & 0.03 & $<0.78^{\mathrm{b}}$ \\
$\mathbf{1 9}$ & $31.0 \pm 12.6$ & 0.6 & $\mathrm{ND}$ & $\mathrm{ND}$ & $45.0 \pm 1.2$ & 0.4 & $\mathrm{ND}$ & $\mathrm{ND}$ & $\mathrm{ND}$ & $\mathrm{ND}$ & $\mathrm{ND}$ & $\mathrm{ND}$ & $19.4 \pm 7.4$
\end{tabular}




$\begin{array}{lllllllllllllll}\mathbf{2 0} & 21.1 \pm 5.7 & 0.05 & \text { ND } & \text { ND } & 23.5 \pm 3.5 & 0.04 & 30.2 \pm 6.3 & 0.7 & 33.7 \pm 2.7 & 0.03 & 18.0 \pm 5.6 & 0.06 & 1.0 \pm 0.4 \\ \mathbf{2 1} & \text { ND } & \text { ND } & \text { ND } & \text { ND } & \text { ND } & \text { ND } & \text { ND } & \text { ND } & \text { ND } & \text { ND } & \text { ND } & \text { ND } & 22.2 \pm 8.4 \\ \mathbf{2 2} & 53.1 \pm 5.2 & 1.2 & \text { ND } & \text { ND } & \text { ND } & \text { ND } & \text { ND } & \text { ND } & \text { ND } & \text { ND } & \text { ND } & \text { ND } & 65.1 \pm 18.1 \\ \mathbf{2 3} & \text { ND } & \text { ND } & \text { ND } & \text { ND } & \text { ND } & \text { ND } & \text { ND } & \text { ND } & \text { ND } & \text { ND } & \text { ND } & \text { ND } & 40.4 \pm 13.2 \\ \mathbf{2 4} & 18.1 \pm 4.1 & 1.7 & \text { ND } & \text { ND } & \text { ND } & \text { ND } & \text { ND } & \text { ND } & 34.5 \pm 4.7 & 0.9 & 22.4 \pm 7.1 & 1.4 & 30.8 \pm 10.3 \\ \mathbf{L A P} & 24.1 \pm 3.4 & 4.1 & >100 & 1 & >100 & 1 & >100 & 1 & >100 & 1 & >100 & 1 & >100^{b} \\ \text { ETP* } & 1.30 \pm 0.7 & 77 & 24.5 \pm 8.4 & 4.1 & 2.4 \pm 0.8 & 42 & 99.3 \pm 5.2 & 1 & >100 & 1 & >100 & 1 & >100^{b} \\ \end{array}$

*Positive control. SI: selectivity index, $\mathrm{SI}=\mathrm{IC}_{50} \mathrm{PBMC} / \mathrm{IC}_{50}$ tumor; ${ }^{\mathrm{a}} \mathrm{IC}_{50}$ : concentration that reduced $50 \%$ of cell viability, values $(\mu \mathrm{M})$ mean \pm S.E.M; $\mathrm{ND}=\mathrm{IC}_{50}$ values were not determined once reduction in $50 \%$ of cell viability was not reached in the tested concentrations; ${ }^{\mathrm{b}}$ Estimated SI: for compounds whose exact $\mathrm{IC}_{50}$ values could not be determined $(<0.78$ or 100$)$ due to low solubility or even at the minimum or maximum concentration evaluated did not reach $50 \%$ reduction in cell viability, the values to estimate the SI was 0.78 or $100 \mu \mathrm{M}$. LAP: lapachol. ETP: etoposide.

Lapachol (1) was active only against $\mathrm{HL} 60$ cell line with an $\mathrm{IC}_{50}=24.1 \mu \mathrm{M}$ and the most of its glycosides were active against at least one tumor cell line. Classical glycosides $\mathbf{5}$ and 14-16 were active against all cancer cell lines, being more active than glycosyl triazoles $\mathbf{1 7 - 2 4}$ for most of the cell lines. Compound 5 was the most active against three cancer cell lines Jurkat, $\mathrm{IC}_{50}=10.2 \mu \mathrm{M}$, THP-1, $\mathrm{IC}_{50}=11.5 \mu \mathrm{M}$ and MDAMB-231, $\left.\mathrm{IC}_{50}=8.2 \mu \mathrm{M}\right)$.MDA-MB-231 is a cell line that lacks hormone receptors $[42,43]$, not responding to anti-hormonal therapy and that may acquire resistance to chemotherapy [44]. Besides, compound $\mathbf{5}$ showed the lower toxicity among all derivatives to non-tumor PBMC presenting the higher selectivity index ( $\mathrm{SI}=9.8$ for HL-60) [45]. Among the classical glycosides compound $\mathbf{1 4}$ was active against MCF-7 (with a $\left.\mathrm{IC}_{50}=31.4 \mu \mathrm{M}\right)$, an estrogen receptor $(\mathrm{ER})$-positive breast cancer cell $[46,47]$ and $\mathrm{HCT}-116\left(\mathrm{IC}_{50}=23.0\right.$ $\mu \mathrm{M}$ ), a resistant cancer cell line [48] and the second least toxic regarding classical glycosides for PBMC $\left(\mathrm{IC}_{50}=5.4 \mu \mathrm{M}\right)$. Compound 15 was the most active against $\mathrm{HL} 60$ with an $\mathrm{IC}_{50}$ value of $4.2 \mu \mathrm{M}$, indicating a potent anticancer activity for this cell line. Compound $\mathbf{1 6}$ was the second more active against Jurkat and HCT-116, with an $\mathrm{IC}_{50}$ of $10.4 \mu \mathrm{M}$ and $24.7 \mu \mathrm{M}$, respectively.

Peracetylated and deacetylated glycosyl triazoles 17-24 were active against at least two cancer cell lines. Compound 17 was active against two cancer cell lines, being the most active against both (THP-1, IC $50=$ $20.8 \mu \mathrm{M}$ and $\left.\mathrm{HL} 60, \mathrm{IC}_{50}=11.6 \mu \mathrm{M}\right)$. Compound $\mathbf{1 8}$ was active against the six cancer cell lines, with higher activity against MCF-7, with an $\mathrm{IC}_{50}=14.3 \mu \mathrm{M}$. Besides, compound $\mathbf{1 8}$ was the only compound to show activity against Jurkat $\left(\mathrm{IC}_{50}=23.0 \mu \mathrm{M}\right)$. Compound $\mathbf{2 0}$ was active against all cancer cell lines, except Jurkat, 
being the most active against HCT-116 $\left(\mathrm{IC}_{50}=18.0 \mu \mathrm{M}\right)$, a resistant cancer cell line [48]. Compounds 18 and $\mathbf{2 0}$ were the only to show activity against MDA-MB-231. Among the deacetylated compounds (21-24), only compounds 22 and $\mathbf{2 4}$ (D-galactose e L-fucose derivatives, respectively) were active. Compound $\mathbf{2 2}$ was active against HL-60 $\left(\mathrm{IC}_{50}=53.1 \mu \mathrm{M}\right)$. Compound 24 was active against $\mathrm{HL}-60\left(\mathrm{IC}_{50}=18.1 \mu \mathrm{M}\right)$, MCF$7\left(\mathrm{IC}_{50}=34.5 \mu \mathrm{M}\right)$ and $\mathrm{HCT}-116\left(\mathrm{IC}_{50}=22.4 \mu \mathrm{M}\right)$. Regarding the toxicity towards PBMC cells, compounds 17, 18, and 20 showed cytotoxicity against PBMC at lower micromolar range $(<10 \mu \mathrm{M})$. Compounds $\mathbf{1 9}$, 21, 23 and 24 displayed toxicity at range of 20 to $40 \mu \mathrm{M}$. Compound 22 was the less cytotoxic to PBMC cells among all new lapachol, derivatives with $\mathrm{IC}_{50}=65 \mu \mathrm{M}$.

The selectivity index (SI) is the ratio between the $\mathrm{IC}_{50}$ towards normal cells and cancer cells. Comparing all analogs, compound 5 was the the most selective, with SI values of 9.8 to HL60, 4.2 to Jurkat, 3.7 to THP-1, 5.2 to MDA-MB-231, 0.9 to MCF-7 and 1.7 to HCT-116. A SI greater than 3 is considered satisfactory for anticancer drugs as reported in the literature $[49,50]$.

\subsubsection{Evaluation of DNA fragmentation assay as indicative of cell death by apoptosis}

The subdiploid DNA quantification accomplished in this work was used as strategy to measure the DNA fragmentation, being an indicative of cell death activation by apoptosis, according described by Nicoletti et al $[51,52]$. According to the protocol used, cells with DNA fragments by death apoptosis process can be evaluated by quantification of subdiploid DNA content. The classical glycosides (compounds 5 and 14-16) presented higher cytotoxicity against the majority of tumor cell lines and the best selectivity index (SI) for at least one tumor cell lines, so they were selected for the quantification of subdiploid DNA content as indicative of the pro-apoptotic potential [51]. There was an increase in subdiploid DNA content in the tumor cell lines treated with classical lapachol glycosides 5 and 14-16, but not with lapachol. The compounds were evaluated in the concentration of $50 \mu \mathrm{M}$ and glycosides induced DNA fragmentation in all tumor cell line (Fig. 7). 


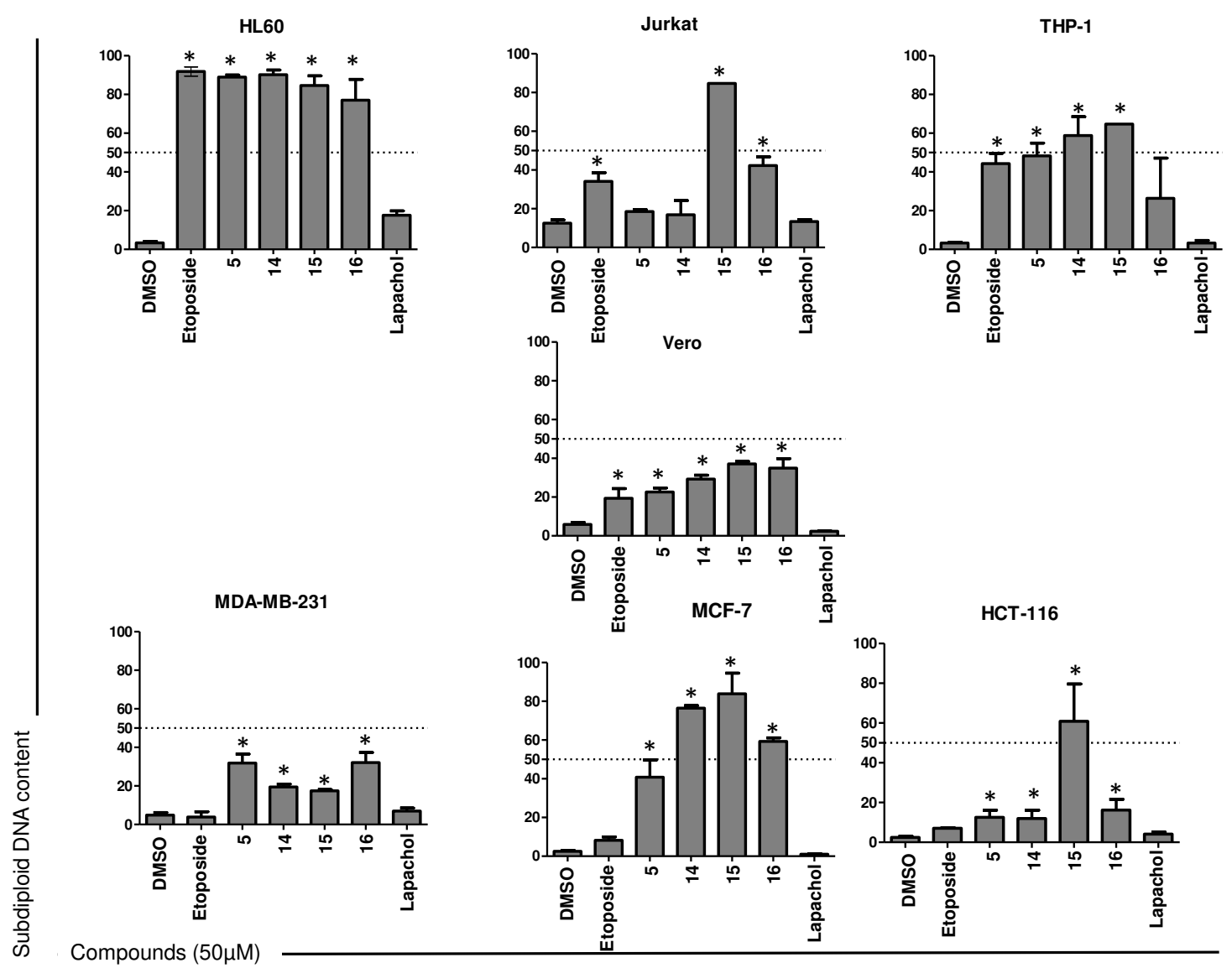

Fig. 7 - Lapachol derivatives, but not Lapachol induces DNA fragmentation in tumor and non-tumor cell lines. Tumor and non-tumor cell lineages were treated with lapachol and derivatives at $50 \mu \mathrm{M}$ for $24 \mathrm{~h}$ and the sub diploid DNA content was measured by flow cytometry. Representative data of three independent experiments (at least) in triplicate.

*Statistically different of control (DMSO 0.5\%), p<0.05.

The more susceptible tumor cell line was HL60 (human myeloid leukemia) for which it was observed a high increase in subdiploid DNA content as compared with control (DMSO, 0.5\%) and lapachol (1). Compound 15 showed high activity against Jurkat cells (human lymphoid leukemia), followed by compound 16. In the other cell lines lapachol did not show activity, but its derivatives were active. Compound 15 was the most active against MCF-7 (derived from ER-positive breast cancer), followed by compounds $\mathbf{1 4}$ and $\mathbf{1 6}$, inducing more than $50 \%$ of DNA fragmentation as compared to compound $\mathbf{5}$. In MDA-MB-231 cells the compounds $\mathbf{5}$ and $\mathbf{1 6}$ showed same percentage of sub diploid DNA content increase 
( $40 \%$ ), being better than compounds $\mathbf{1 4}$ and 15. For HCT-116 (colorectal carcinoma) compound $\mathbf{1 5}$ was the only active.

A common characteristic of cell lines used in this work is related to presence or absence of checkpoint p53 protein activity. The leukemic cell lines HL60, Jurkat and THP-1 lack p53 protein [53-55]. It is interesting to note that for HL60 and THP-1 cells the majority of compounds (except $\mathbf{1 6}$ for THP-1) showed similar activity. Compound 15 presented good activity against Jurkat and HCT-116 cell lines, being the most active of all compounds for these lineages.

The compounds 5 and $\mathbf{1 4}$ did not induce the DNA fragmentation in Jurkat (p53 null) and HCT-116 (p53 wild type) cell lines as compared to control (DMSO, 0.5\%). Compound 16 increased the DNA fragmentation in all tumor cell lines (with or without p53) except HCT-116. The three cell lines from solid tumors also differ from each other in regard to 53 protein which is absent in MDA-MB-231 and present in MCF-7 and HCT-116, both p53 wild type [56-58]. When comparing the effect of compounds $\mathbf{1 4}$ and $\mathbf{1 5}$ with compounds 5 and 16, the last were more active against MDA-MB-231 and less active against MCF7. Compound $\mathbf{1 5}$ (derived from D- $N$-acetylglucosamine) was active against all tumor cell lines, including the lineages with protein p53 wild type (MCF-7 and HCT-116), being the only one that induced DNA fragmentation in HCT-116 as compared to lapachol and its other glycosides $(\mathbf{5}, \mathbf{1 4}$ and $\mathbf{1 6})$. The HCT-116 cell line showed p53 wild type protein [59] and the activity of chemotherapeutics may be mediated by p53 and Bax pro-apoptotic proteins which activate the apoptosis mitochondrial pathway and can activate caspase-3 [58]. On this way, the MCF-7 cells are the only ones used in this work that lack caspase-3 [60]. For MCF-7 cells other mechanisms of apoptosis induced by different chemotherapeutic agents may occur independently of caspase- 3 so that DNA fragmentation can be observed despite the absence of caspase- 3 [60]. Therefore, different pathways should be involved in the pro-apoptotic potential observed for new lapachol glycosides.

\subsubsection{Effect of lapachol glycosides in the clonogenic survival of solid tumor lineages}

Is well known that the DNA damage inducing agents induce cell cycle arrest at checkpoints. This is a cell survival response that allows them to repair damaged DNA and is not directly related to cell death. Cells that have the function of the p53 checkpoint protein present stop the cycle. They may show loss of viability, displaying lower values of $\mathrm{IC}_{50}$, but may show increased of survival. While relative $\mathrm{IC}_{50}$ values may allow 
comparison between compounds, they do not predict cell survival. In addition, the assays for evaluation of subdiploid DNA content allow to evaluate cell death, but do not the cell survival after discontinuation of treatment [61]. The clonogenicity is related to the ability of a single cell to grow into a colony. Therefore, a compound that in addition to reducing cell proliferation, also inactivate clonogenic cells, shows a most efficiency. Thereby, the clonogenicity assay aims to indicate if the clonogenic tumoral cells are proliferating. And this is one characteristic responsible for tumor recurrence. To perform the clonogenicity assay, it was selected the lineages more susceptible. All compounds in the concentration of their $\mathrm{IC}_{50}$ values inhibited the clonogenic survival of MCF-7, HCT-116 and MDA-MB-231 after $24 \mathrm{~h}$ of treatment despite showing different results of DNA fragmentation in these cell lines. Compounds 5, 14 and $\mathbf{1 6}$ although not inducing DNA fragmentation in HCT-116 cells, reduced their ability to form colonies, similar to compound 16, the only one that induced DNA fragmentation in HCT-116 cells (Fig. 8). Both lapachol (1) and etoposide, inactive against these cells, were not evaluated in the clonogenicity assay. The activity of the new lapachol classical glycosides is similar among them, not being possible to observe differences in the colony formation in the assays, but certainly were more efficient to inhibit the survival of clonogenic cells of the three tested lineages, when compared with lapachol.
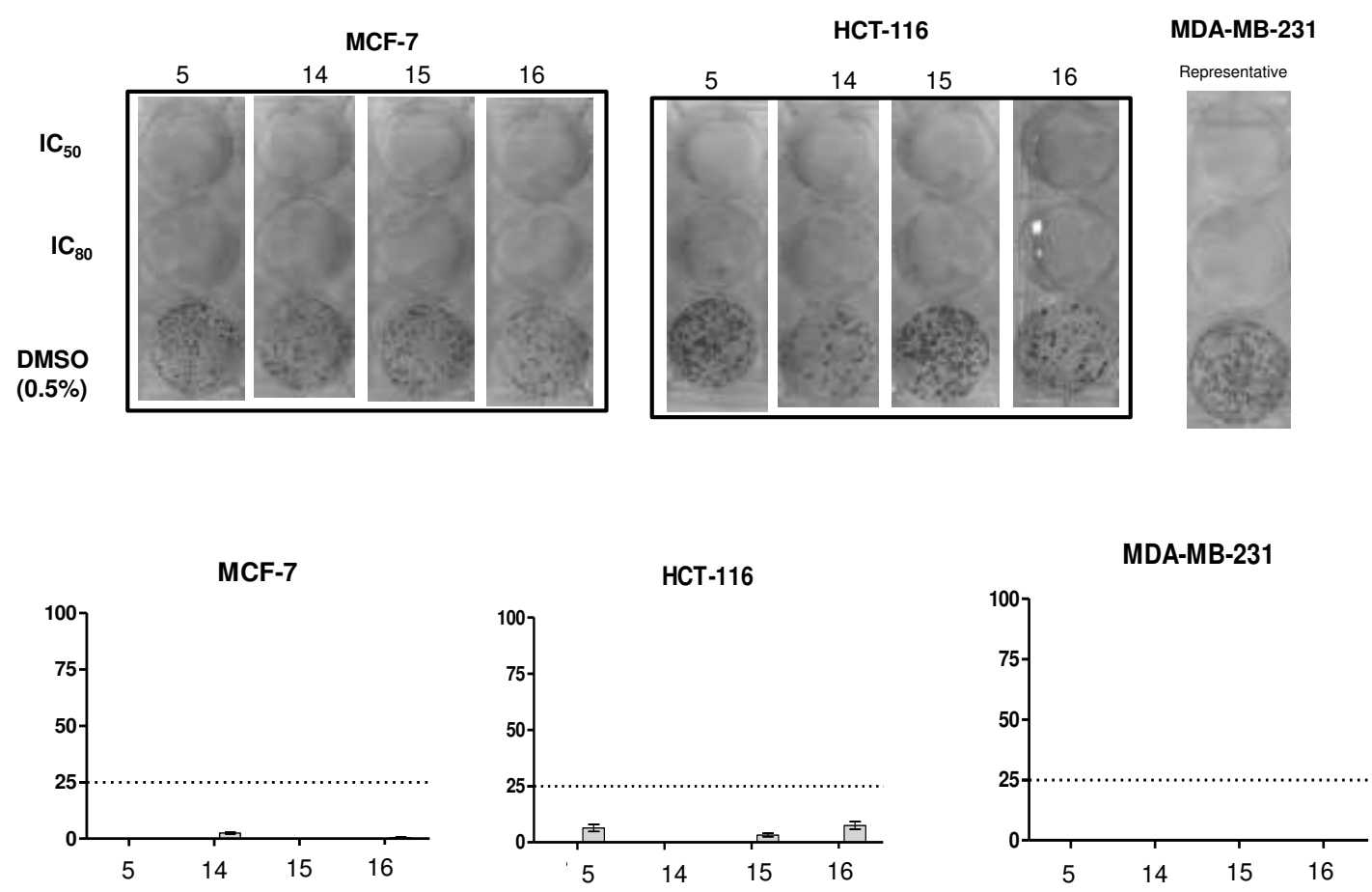

Fig. 8 - Impact of Lapachol and derivatives on clonogenic survival of MCF-7, MDA-MB-231 and HCT-116 lineages. Cells were treated with compounds at $\mathrm{IC}_{50}$ and $\mathrm{IC}_{80}$ values for $24 \mathrm{~h}$, washed, the medium was replaced and incubated for 15 days. Representative images of colony formation after treatment of MCF-7 and HCT-116 with analogs is demonstrated. To MDA-MB-231, no colonies grew after treatment with all analogs and it is demonstrated one representative image. At least, two independent experiments were 
performed in triplicate. Colonies of more than 50 cells were counted, and the surviving fraction was calculated relative to control (DMSO, $0.5 \%$ ) to account for basal plating efficiencies

\subsection{Influences of the chemical structure of lapachol glycosides on bioactivity}

The cytotoxicity against the evaluated cancer cell lines was in general higher for lapachol glycosides $(\mathbf{5}$, 14-16, 17-20, 22 and 24) than that of lapachol (1), indicating that carbohydrate moieties influenced in the cytotoxicity against tumoral and non-tumoral cells. The higher activity of peracetylated lapachol glycosides can be explained due the presence of the $O$-acetyl groups on saccharidic moiety, which impair appropriate liposolubility to the peracetylated glycosides enabling these compounds to cross the cell membrane [13]. The presence of hexose transporters on cell surface [21] may have facilitated the entry of the deacetylated lapachol glycosides that were active.

The nature of the carbohydrate moieties seems to influence on activity, wherein the variation of sugar improves or reduces the cytotoxic activity. For example, the peracetylated lapachol glycosyl triazole derived from L-fucose (20) was the most active against HCT-116 while its deacetylated analogue (compound 24) was the second more active against this lineage, indicating that L-fucose residue improves the activity. The L-fucose is the only carbohydrate on the $\mathrm{L}$ series, all the others belonging to the $\mathrm{D}$ series. Unlike the other carbohydrate moieties L-fucose has a methyl group attached to C-5 of the pyranose ring, while the other compounds bear a more polar hydroxymethyl group at this position. The greater lipophilic character of the sugar portion of compound $\mathbf{2 4}$ apparently contributed to a better hydrophilic/lipophilic balance of the compound when compared with the other compounds of this series (21-23), which resulted in greater activity of $\mathbf{2 4}$. The presence of triazole ring led to reduction of activity of the glycosyl triazoles as compared to classical lapachol glycosides. It is interesting to note that the presence of the acetamido (NHAc) group at C-2 in compound $\mathbf{1 5}$ improved its activity in regard to the other compounds as such compound showed good activity against all tumor cell lines in the DNA fragmentation assay, being the most active against Jurkat and HCT-116. For this last lineage, compound $\mathbf{1 5}$ was the only able to impair DNA fragmentation beyond $50 \%$. 


\section{Conclusions}

The synthesis of 12 lapachol-based glycosides and glycosyl triazoes and evaluation against several cancer cell lines is described in the present work.

Compound $\mathbf{5}$ was far more active than lapachol (1) and about four to ten times more active in tumor cell lines HL60, Jurkat, THP-1 and MDA-MB-231 than in the non-tumoral PBMC cell line, which represents an important improvement in activity and selectivity as compared with lapachol (1). These results clearly suggest that structural modifications of the parent structure 1 with carbohydrates can produce more potent and more selective new derivatives.

Compounds 5 and 14-16 evaluated in the DNA fragmentation and clonogenicity assays showed good results in the studies of subdiploid DNA content, indicating a pro-apoptotic potential. Moreover, these compounds presented good results in the clonogenicity assays, evidencing cytotoxicity for all tumor cell lines concerning clonogenic cells, which are able of to form colonies.

The greater lipophilic character of the peracetylated classic glycosides 5, 14-16 and glycosyl triazoles 1720 is probably one of the main reasons for their greater activity as compared with the deacetylated ones. In conclusion, the modification of lapachol (1) with glycosyl and glycosyl triazole moieties furnished compounds with greater activity and wider spectrum of action than the parent compound and can be exploited for the development of new anticancer agents.

\section{Material and Methods}

\subsection{Chemistry}

\subsubsection{General procedure for the synthesis of peracetylated lapachol glycosides (5 and 14-16)}

Lapachol (1, $1.0 \mathrm{mmol})$ was solubilized in $5 \mathrm{~mL}$ of dichloromethane and was added $5 \mathrm{~mL}$ of sodium carbonate $10 \% \mathrm{w} / \mathrm{v}$ solution and tetrabutylammonium bromide $(0.3 \mathrm{mmol})$. Then a solution of the appropriate glycosyl halide $(3.0 \mathrm{mmol})$ in $5 \mathrm{~mL}$ of dichloromethane was added. The reaction mixture was stirred at room temperature for $24 \mathrm{~h}$, monitoring by TLC analysis. A $6 \mathrm{~mol} \mathrm{~L}^{-1} \mathrm{HCl}(50 \mathrm{~mL})$ solution was added until $\mathrm{pH}=4$ and the mixture was transferred to a separatory funnel. The organic layer was separated and the aqueous phase was extracted with $3 \times 50 \mathrm{~mL}$ of dichloromethane. The combined organic layers were washed with water $(3 \times 25 \mathrm{~mL})$, dried over anhydrous sodium sulfate and concentrated under reduced 
pressure. The crude classical lapachol glycosides obtained from D-glucose (5), D-galactose (14), D- $N$ acetylglucosamine (15) and L-fucose (16) were purified by recrystallization from methanol.

4.2.1.1 2-(2,3,4,6-tetra-O-acetyl- $\beta$-D-glucopyranosyloxy)-3-(3-methyl-2-butenyl)-1,4-naphthoquinone (5). Yield: $60 \%$; mp $60.2-66.9^{\circ} \mathrm{C}$ (Lit: $\left.62-65^{\circ} \mathrm{C}\right)[13] ;[\alpha]_{\mathrm{D}}^{20}-114.3\left(c 0.42 ; \mathrm{CHCl}_{3}\right) ; \mathrm{IR} v_{\max } 2939,1748$, 1667, 1592, 1573, 1213, $1035 \mathrm{~cm}^{-1} ;{ }^{1} \mathrm{H}$ NMR $\left(\mathrm{CDCl}_{3}, 400 \mathrm{MHz}\right) \delta 1.66\left(3 \mathrm{H}, \mathrm{s}, \mathrm{CH}_{3}, \mathrm{H}-15^{\prime}\right), 1.79(3 \mathrm{H}, \mathrm{s}$, $\mathrm{CH}_{3}, \mathrm{H}-14$ '), 1.98-2.12 (12H, s, $\left.\mathrm{CH}_{3}, \mathrm{CH}_{3} \mathrm{CO}\right), 3.29$ (1H, dd, $J=7.0,13.1 \mathrm{~Hz}, \mathrm{H}-11$ 'a), 3.37 (1H, dd, $J=$ 7.7, $13.1 \mathrm{~Hz}, \mathrm{H}-11$ 'b), 3.76 (1H, ddd, $J=2.4,4.6,10.0 \mathrm{~Hz}, \mathrm{H}-5), 4.06(1 \mathrm{H}, \mathrm{dd}, J=2.2,12.4 \mathrm{~Hz}, \mathrm{H}-6 \mathrm{a})$, $4.21(1 \mathrm{H}, \mathrm{dd}, J=4.7,12.4 \mathrm{~Hz}, \mathrm{H}-6 \mathrm{~b}), 5.10(1 \mathrm{H}, \mathrm{t}, J=7.2 \mathrm{~Hz}, \mathrm{H}-12$ '), $5.15(1 \mathrm{H}, \mathrm{d}, J=9.6 \mathrm{~Hz}, \mathrm{H}-4), 5.26$ $(1 \mathrm{H}, \mathrm{dd}, J=7.8 \mathrm{~Hz}, 9.4 \mathrm{~Hz}, \mathrm{H}-2), 5.33(1 \mathrm{H}, \mathrm{t}, J=9.3 \mathrm{~Hz}, \mathrm{H}-3), 5.82(1 \mathrm{H}, \mathrm{d}, J=7.7 \mathrm{~Hz}, \mathrm{H}-1), 7.68-7.73$ (2H, m, H-6' and H-7'), 8.03-8.08 (2H, m, H-5' and H-8'); ${ }^{13} \mathrm{C}^{\prime} \mathrm{NMR}\left(\mathrm{CDCl}_{3}, 100 \mathrm{MHz}\right) \delta 18.0\left(\mathrm{CH}_{3}, \mathrm{C}-\right.$ 14'), 20.6-20.7 ( $\left.\mathrm{CH}_{3}, \underline{\mathrm{CH}}_{3} \mathrm{CO}\right), 23.4\left(\mathrm{CH}_{2}, \mathrm{C}-11^{\prime}\right), 25.8\left(\mathrm{CH}_{3}, \mathrm{C}-15^{\prime}\right), 61.6\left(\mathrm{CH}_{2}, \mathrm{C}-6\right), 68.3(\mathrm{CH}, \mathrm{C}-4)$, 71.7 (CH, C-2), 72.2 (CH, C-5), 72.7 (CH, C-3), 99.1 (CH, C-1), 119.3 (CH, C-12'), 126.1 (CH, C-5'), 126.5 (CH, C-8'), 131.3 (C, C-10'), 132.0 (C, C-9'), 133.5 (CH, C-6'), 134.0 (CH, C-7'), 134.2 (C, C-13'), 137.7 (C, C-3'),152.5 (C, C-2'), 169.4-170.5 (C, $\left.\mathrm{COCH}_{3}\right), 181.0$ (CO, C-4'), 184.9 (CO, C-1'); UPLC purity $=98 \%, \mathrm{tR}=7.00 \mathrm{~min} ; \mathrm{HRMS}\left(\mathrm{ESI}^{+}\right) \mathrm{m} / z$ calcd for $\mathrm{C}_{29} \mathrm{H}_{33} \mathrm{O}_{12}$ 573.20, found $573.25\left(\mathrm{M}+\mathrm{H}^{+}\right)$.

4.2.1.2 2-(2,3,4,6-tetra- $O$-acetyl- $\beta$-D-galactopyranosyloxy)-3-(3-methyl-2-butenyl)-1,4-naphthoquinone (14).

Yield: 60\%; mp $62.5-65.3^{\circ} \mathrm{C} .[\alpha]_{\mathrm{D}}^{20}-92.7\left(c 0.41 ; \mathrm{CHCl}_{3}\right)$; IR $v_{\max } 2940,1748,1667,1213,1048 \mathrm{~cm}^{-1}$; ${ }^{1} \mathrm{H}$ NMR $\left(\mathrm{CDCl}_{3}, 400 \mathrm{MHz}\right) \delta 1.68\left(3 \mathrm{H}, \mathrm{s}, \mathrm{CH}_{3}, \mathrm{H}-15^{\prime}\right), 1.82\left(3 \mathrm{H}, \mathrm{s}, \mathrm{CH}_{3}, \mathrm{H}-14\right.$ ') $1.94-2.18\left(12 \mathrm{H}, \mathrm{s}, \mathrm{CH}_{3}\right.$, $\left.\mathrm{C}_{3} \underline{\mathrm{CO}}\right), 3.32\left(1 \mathrm{H}, \mathrm{dd}, J=7.2,13.0 \mathrm{~Hz}, \mathrm{H}-11^{\prime}\right.$ 'a), 3.39 (1H, dd, $J=7.7,13.0 \mathrm{~Hz}, \mathrm{H}-11$ 'b), 3.95 (1H, t, $J=$ 6.6 Hz, H-5), 4.05 (1H, dd, $J=6.4,11.2 \mathrm{~Hz}, \mathrm{H}-6 \mathrm{a}), 4.10(1 \mathrm{H}, \mathrm{dd}, J=7.3,11.3 \mathrm{~Hz}, \mathrm{H}-6 \mathrm{~b}), 5.11-5.16(1 \mathrm{H}$, m, H-12'), $5.14(1 \mathrm{H}, \mathrm{dd}, J=3.3,10.4 \mathrm{~Hz}, \mathrm{H}-3), 5.42-5.46(2 \mathrm{H}, \mathrm{m}, \mathrm{H}-4$ and $\mathrm{H}-2), 5.74(1 \mathrm{H}, \mathrm{d}, J=8.6 \mathrm{~Hz}$,

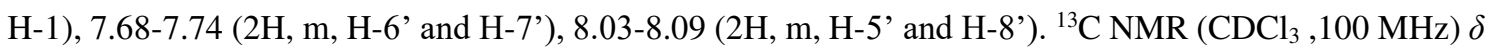
$18.0\left(\mathrm{CH}_{3}, \mathrm{C}-14\right.$ '), 20.5-20.9 ( $\left.\mathrm{CH}_{3}, \mathrm{CH}_{3} \mathrm{C}=\mathrm{O}\right), 23.5\left(\mathrm{CH}_{2}, \mathrm{C}-11^{\prime}\right), 25.8\left(\mathrm{CH}_{3}, \mathrm{C}-15^{\prime}\right), 60.9\left(\mathrm{CH}_{2}, \mathrm{C}-6\right), 66.9$ (CH, C-5), 69.2 (CH, C-4), 70.7 (CH, C-3), 71.2 (CH, C-2), 99.6 (CH, C-1), $119.4(\mathrm{CH}, \mathrm{C}-12$ '), 126.1 (CH, C-5'), 126.5 (CH, C-8'), 131.3 (C, C-10'), 132.0 (C, C-9'), 133.4 (CH, C-6'), 134.0 (CH, C-7'), 134.0 (C, 
C-13'), 137.9 (C, C-3'), 152.6 (C, C-2'), 169.7-170.2 (C, $\underline{\mathrm{COCH}}_{3}$ ), 181.0 (CO, C-4'), 184.9 (CO, C-1'); UPLC purity $=98 \%, \mathrm{tR}=6.95 \mathrm{~min} ; \mathrm{HRMS}\left(\mathrm{ESI}^{+}\right) \mathrm{m} / z$ calcd for $\mathrm{C}_{29} \mathrm{H}_{33} \mathrm{O}_{12} 573.20$, found $573.25\left(\mathrm{M}+\mathrm{H}^{+}\right)$.

4.2.1.3 2-(2-acetamido-3,4,6-tri-O-acetyl-2-deoxy- $\beta$-D-glucopyranosyloxy)-3-(3-methyl-2-butenyl)1,4-naphthoquinone (15).

Yield: 70\%; mp $142.4-144.1^{\circ} \mathrm{C}$. $[\alpha]_{\mathrm{D}}^{20}-85.7^{\circ}\left(c 0.42 ; \mathrm{CHCl}_{3}\right)$; IR $v_{\max } 3308,2931,1742,1666,1621$, 1593, 1539, 1224, 1191, $1043 \mathrm{~cm}^{-1} ;{ }^{1} \mathrm{H}$ NMR $\left(\mathrm{CDCl}_{3}, 400 \mathrm{MHz}\right) \delta 1.66$ (3H, s, $\left.\mathrm{CH}_{3}, \mathrm{H}-15^{\prime}\right), 1.79$ (3H, s, $\mathrm{CH}_{3}, \mathrm{H}-14$ '), 2.02-2.07 (12H, s, $\left.\mathrm{CH}_{3}, \mathrm{C}_{3} \mathrm{CO}\right), 3.31$ (1H, dd, $J=6.8,13.2 \mathrm{~Hz}, \mathrm{H}-11$ 'a), 3.43 (1H, dd, $J=$ 7.9, $13.0 \mathrm{~Hz}, \mathrm{H}-11$ 'b), 3.64-3.68 (1H, m, H-5), 4.08 (1H, dd, $J=2.3,12.3 \mathrm{~Hz}, \mathrm{H}-6 \mathrm{a}), 4.21$ (1H, dd, $J=4.6$, 12.4 Hz, H-6b), 4.37-4.44 (1H, m, H-2), 5.11 (1H, t, $J=7.2 \mathrm{~Hz}, \mathrm{H}-12$ '), 5.15-5.21 (2H, m, H-3 and H-4), $5.36(1 \mathrm{H}, \mathrm{d}, J=8.6 \mathrm{~Hz}, \mathrm{H}-1), 6.35\left(1 \mathrm{H}, \mathrm{d}, J=8.6 \mathrm{~Hz}, \mathrm{NHCOCH}_{3}\right), 7.70-7.76(2 \mathrm{H} ; \mathrm{m}, \mathrm{H}-6$ ' and H-7'), 8.04$8.10\left(2 \mathrm{H}, \mathrm{m}, \mathrm{H}-5\right.$ ' and H-8'); ${ }^{13} \mathrm{C}$ NMR $\left(\mathrm{CDCl}_{3}, 100 \mathrm{MHz}\right) \delta 18.0\left(\mathrm{CH}_{3}, \mathrm{C}-14\right.$ '), 20.6-20.7 $\left(\mathrm{CH}_{3}, \underline{\mathrm{CH}}_{3} \mathrm{C}=\mathrm{O}\right)$, $23.4\left(\mathrm{CH}_{3}, \mathrm{CH}_{3} \mathrm{C}=\mathrm{O}\right.$ amide $), 23.6\left(\mathrm{CH}_{2}, \mathrm{C}-11^{\prime}\right), 25.8\left(\mathrm{CH}_{3}, \mathrm{C}-15^{\prime}\right), 54.3(\mathrm{CH}, \mathrm{C}-2), 61.8\left(\mathrm{CH}_{2}, \mathrm{C}-6\right), 68.1$ (CH, C-5), 72.5 (CH, C-4), 73.3 (CH, C-3), 100.4 (CH, C-1), 119.2 (CH, C-12'), 126.3 (CH, C-5'), 126.7 (CH, C-8'), 131.1 (C, C-10'), 132.1 (C, C-9’), 133.6 (CH, C-6'), 134.3 (CH, C-7'), 134.4 (C, C-13'), 139.1 (C, C-3'), 153.2 (C, C-2'), 169.3 (C, $\left.\mathrm{NH}^{-} \mathrm{COCH}_{3}\right)$, 170.6-171.0 (C, $\left.\underline{\mathrm{COCH}}_{3}\right), 181.7$ (CO, C-4'), 184.8 (CO, $\left.\mathrm{C}-1^{\prime}\right)$; UPLC purity $=96 \%, \mathrm{tR}=5.93 \mathrm{~min} ; \mathrm{HRMS}\left(\mathrm{ESI}^{+}\right) \mathrm{m} / z$ calcd for $\mathrm{C}_{29} \mathrm{H}_{34} \mathrm{NO}_{11} 572.21$, found 571.88 $\left(\mathrm{M}+\mathrm{H}^{+}\right)$.

\subsubsection{2-(2,3,4-tri-O-acetyl-6-deoxy- $\beta$-L-galactopyranosyloxy)-3-(3-methyl-2-butenyl)-1,4-naph-} thoquinone (16).

Yield: $80 \%$; mp $93.6-95.1{ }^{\circ} \mathrm{C} .[\alpha]_{\mathrm{D}}^{27}+104.2^{\circ}\left(c 0.48 ; \mathrm{CHCl}_{3}\right)$. IR $v_{\max } 2961,2858,1748,1668,1618$, 1594, 1216, 1195, 1056, $1021 \mathrm{~cm}^{-1} ;{ }^{1} \mathrm{H}$ NMR $\left(\mathrm{CDCl}_{3}, 400 \mathrm{MHz}\right): \delta 1.14\left(3 \mathrm{H}, \mathrm{d}, J=6.4 \mathrm{~Hz}, \mathrm{CH}_{3}, \mathrm{H}-6\right)$, $1.68\left(3 \mathrm{H}, \mathrm{s}, \mathrm{CH}_{3}, \mathrm{H}-15^{\prime}\right), 1.83$ (3H, s, $\left.\mathrm{CH}_{3}, \mathrm{H}-14^{\prime}\right), 2.02-2.20$ (9H, s, $\mathrm{CH}_{3}, \mathrm{C}_{3} \mathrm{CO}$ ), 3.33 (1H, dd, J = 7.0, 13.0 Hz, H-11'a), 3.43 (1H, dd, $J=7.8,13.0 \mathrm{~Hz}, \mathrm{H}-11^{\prime}$ b), 3.83 (1H, d, $\left.J=6.4 \mathrm{~Hz}, \mathrm{H}-5\right), 5.11-5.18(1 \mathrm{H}, \mathrm{m}$, H-12'), $5.12(1 \mathrm{H}, \mathrm{dd}, J=3.4,10.4 \mathrm{~Hz}, \mathrm{H}-3), 5.26(1 \mathrm{H}, \mathrm{d}, J=2.9 \mathrm{~Hz}, \mathrm{H}-4), 5.41(1 \mathrm{H}, \mathrm{dd}, J=7.9,10.4 \mathrm{~Hz}$, H-2), 5.70 (1H, d, $J=7.9 \mathrm{~Hz}, \mathrm{H}-1), 7.68-7.73$ (2H, m, H-6' and H-7'), 8.02-8.08 (2H, m, H-5' and H-8')

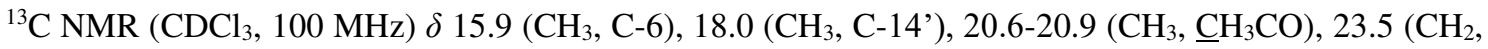
C-11'), $25.8\left(\mathrm{CH}_{3}, \mathrm{C}-15^{\prime}\right), 69.2\left(\mathrm{CH}_{2}, \mathrm{C}-5\right), 69.7(\mathrm{CH}, \mathrm{C}-4), 70.1$ (CH, C-3), $71.1(\mathrm{CH}, \mathrm{C}-2), 99.6(\mathrm{CH}, \mathrm{C}-$ 1), 119.6 (CH, C-12'), 126.1 (CH, C-5'), 126.4 (CH, C-8'), 131.3 (C, C-10'), 132.0 (C, C-9'), 133.4 (CH,

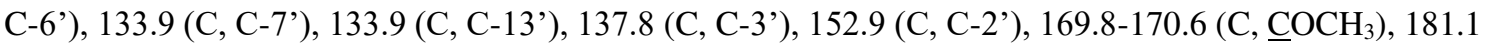


$\left(\mathrm{CO}, \mathrm{C}^{\prime} 4^{\prime}\right), 185.1\left(\mathrm{CO}, \mathrm{C}-1^{\prime}\right)$; UPLC purity $=99 \%, \mathrm{tR}=7.18 \mathrm{~min} ; \mathrm{HRMS}\left(\mathrm{ESI}^{+}\right) \mathrm{m} / z$ calcd for $\mathrm{C}_{27} \mathrm{H}_{31} \mathrm{O}_{10}$ 515.19, found $515.24\left(\mathrm{M}+\mathrm{H}^{+}\right)$.

\subsubsection{Synthesis of 2-[(2-propyn-1-yl)oxy]3-(3-methyl-2-butenyl)-1,4-naphthoquinone (28)}

Lapachol (1.0 g, $4.12 \mathrm{mmol})$ was dissolved in $20 \mathrm{~mL}$ of $\mathrm{CH}_{2} \mathrm{Cl}_{2}$ in a $100 \mathrm{~mL}$ round bottom flask, followed by addition of $20 \mathrm{~mL}$ of a $5 \% \mathrm{w} / \mathrm{v} \mathrm{K}_{2} \mathrm{CO}_{3}$ solution $(1.0 \mathrm{~g}, 7.24 \mathrm{mmol})$ and the mixture was stirred at room temperature for 30 minutes. Tetra- $n$-butylammonium bromide $(0.1 \mathrm{~g}, 0.31 \mathrm{mmol})$ and propargyl bromide $(1.0 \mathrm{~mL}, 6.72 \mathrm{mmol})$ were added and the reaction mixture was stirred at room temperature. After six hours additional propargyl bromide $(0.50 \mathrm{~mL}, 3.36 \mathrm{mmol})$ was added and evolution of the reaction was monitored by TLC analysis. After $24 \mathrm{~h}$, the reaction mixture was transferred to a separatory funnel, the organic phase was separated and the aqueous phase was extracted with $3 \times 50 \mathrm{~mL} \mathrm{CH}_{2} \mathrm{Cl}_{2}$. The combined organic phases were washed with water $(6 \times 50 \mathrm{~mL})$, dried over anhydrous $\mathrm{Na}_{2} \mathrm{SO}_{4}$, filtered and concentrated to dryness. The crude product was treated with hexane $(200 \mathrm{~mL})$ and the solvent was evaporated to give a solid that was recrystallized from hot methanol to give compound $\mathbf{2 8}$ as a yellow solid.

Yield: 67\%; mp $39.4-41.4{ }^{\circ} \mathrm{C}$ (Lit: $54-55{ }^{\circ} \mathrm{C}$ ) [62]; IR $v_{\max } 3355,3279,2964,2853,2124,1660,1640$, 1610, 1593, 1579, 1334, 1186, $1047 \mathrm{~cm}^{-1},{ }^{1} \mathrm{H}$ NMR $\left(\mathrm{CDCl}_{3}, 400 \mathrm{MHz}\right) \delta 1.68\left(3 \mathrm{H}, \mathrm{s}, \mathrm{CH}_{3}, \mathrm{H}-15\right), 1.80$ $\left(3 \mathrm{H}, \mathrm{s}, \mathrm{CH}_{3}, \mathrm{H}-14\right), 2.51(1 \mathrm{H}, \mathrm{t}, J=2.4 \mathrm{~Hz}, \mathrm{H}-18), 3.36(2 \mathrm{H}, \mathrm{d}, J=7.2 \mathrm{~Hz}, \mathrm{H}-11), 5.13(2 \mathrm{H}, \mathrm{d}, J=2,4 \mathrm{~Hz}$, $\mathrm{H}-16), 5.15-5.17(1 \mathrm{H}, \mathrm{m}, \mathrm{H}-12), 7.67-7.72(2 \mathrm{H}, \mathrm{m}, \mathrm{H}-6$ and $\mathrm{H}-7), 8.04-8.09(2 \mathrm{H}, \mathrm{m}, \mathrm{H}-5$ and $\mathrm{H}-8) ;{ }^{13} \mathrm{C}$ NMR $\left(\mathrm{CDCl}_{3}, 100 \mathrm{MHz}\right) \delta 18.0\left(\mathrm{CH}_{3}, \mathrm{C}-14\right), 23.3\left(\mathrm{CH}_{2}, \mathrm{C}-11\right), 25.8\left(\mathrm{CH}_{2}, \mathrm{C}-15\right), 60.3\left(\mathrm{CH}_{2}, \mathrm{C}-16\right), 76.4$ (C, C-17), 78.4 (CH, C-18), 119.8 (CH, C-12), 126.2 (CH, C-5), 126.4 (CH, C-8), 131.4 (C, C-9), 132.1 (C, C-9), 133.3 (CH, C-6), 133.9 (CH, C-7), 133.9 (C, C-13), 136.8 (CH, C-3), 155.0 (C, C-2), 181.7 (CO, C-1), $185.1(\mathrm{CO}, \mathrm{C}-4)$.

\subsubsection{General procedure for the synthesis of lapachol glycosyl triazoles (17-24)}

To a $50 \mathrm{~mL}$ round bottom flask was added $28(0.30 \mathrm{mmol})$ dissolved in $1 \mathrm{~mL}$ of tetrahydrofuran, followed by the appropriate glycosyl azide $(0.27 \mathrm{mmol})$, dissolved in $0.5 \mathrm{~mL}$ of tetrahydrofuran. Then, $\mathrm{Cu}(\mathrm{OAc})_{2} \cdot \mathrm{H}_{2} \mathrm{O} 50 \% \mathrm{~mol}$, dissolved in $0.5 \mathrm{~mL}$ of water and sodium ascorbate $60 \%$ mol, dissolved in $1 \mathrm{~mL}$ of water were added in a stepwise manner. The reaction mixture was stirred at room temperature for $4 \mathrm{~h}$ and monitored by TLC analysis. The tetrahydrofuran was removed by distillation at reduced pressure. For 
peracetylated glycosyl triazoles the reaction residues were solubilized in $50 \mathrm{~mL} \mathrm{CH}_{2} \mathrm{Cl}_{2}$ and washed with 2 x $50 \mathrm{~mL} \mathrm{H}_{2} \mathrm{O}$ and subsequently washed with $3 \times 50 \mathrm{~mL}$ alkaline EDTA $20 \% \mathrm{w} / \mathrm{v}$. The organic phase was dried over $\mathrm{Na}_{2} \mathrm{SO}_{4}$ and filtered. The organic phase was removed by distillation at reduced pressure. The deacetylated glycosyl triazoles (21-24) were purified directly. The derivatives 17-20 were added to Florisil and purified with silica column with following mobile phase $\left(\mathrm{CH}_{2} \mathrm{Cl}_{2}\right.$ : ethyl acetate/4:6) and the deacetylated using ethyl acetate: $\mathrm{MeOH} / 9: 1$ as mobile phase.

4.2.3.1 2-[1-(2,3,4,6-tetra-O-acetyl- $\beta$-D-glucopyranosyl)-1,2,3-triazol-4-(methyl)oxy]-3-(3-methyl-2butenyl)-1,4-naphthoquinone (17).

Yield: $68 \%$; mp $158.5-159.6^{\circ} \mathrm{C}$. $[\alpha]_{\mathrm{D}}^{20}-39.4$ (c 0.38; acetone); IR $v_{\max } 2914,1739,1667,1652,1605$, 1254, $1195,1040 \mathrm{~cm}^{-1} ;{ }^{1} \mathrm{H}$ NMR (DMSO- $\left.d_{6}, 400 \mathrm{MHz}\right): \delta 1.62\left(3 \mathrm{H}, \mathrm{s}, \mathrm{CH}_{3}, \mathrm{H}-15^{\prime}\right), 1.72\left(3 \mathrm{H}, \mathrm{s}, \mathrm{CH}_{3}, \mathrm{H}-\right.$ 14'), 1.98-2.05 (12H, s, $\left.\mathrm{CH}_{3}, \mathrm{C}_{3} \mathrm{CO}\right), 3.05\left(2 \mathrm{H}, \mathrm{d}, J=8.0 \mathrm{~Hz}, \mathrm{H}-11^{\prime}\right), 4.08(1 \mathrm{H}, \mathrm{dd}, J=2.4,12.4 \mathrm{~Hz}, \mathrm{H}-$ 6a), 4.14 (1H, dd, $J=5.2,12.4 \mathrm{~Hz}, \mathrm{H}-6 \mathrm{~b}), 4.36-4.40$ (1H, m, H-5), 4.94 (1H, t, $J=7.2 \mathrm{~Hz}, \mathrm{H}-12$ '), 5.19 $(1 \mathrm{H}, \mathrm{d}, J=9.6 \mathrm{~Hz}, \mathrm{H}-4), 5.49-5.59$ (3H, m, H-2and H-16'), $5.65(1 \mathrm{H}, \mathrm{t}, J=9.2 \mathrm{~Hz}, \mathrm{H}-3), 6.37(1 \mathrm{H}, \mathrm{d}, J=$ $9.2 \mathrm{~Hz}, \mathrm{H}-1), 7.85-7.89$ (2H, m, H-6' and H-7'), 8.00 (1H, dd, $J=4.0,8.0 \mathrm{~Hz}, \mathrm{H}-5$ '), 8.04 (1H, dd, $J=4.0$, $\left.8.0 \mathrm{~Hz}, \mathrm{H}-8^{\prime}\right), 8.55$ (1H, s, H-18'); ${ }^{13} \mathrm{C}$ NMR (DMSO- $\left.d_{6}, 100 \mathrm{MHz}\right) \delta 18.1\left(\mathrm{CH}_{3}, \mathrm{C}-14\right.$ '), 20.1-20.9 $\left(\mathrm{CH}_{3}\right.$, $\left.\mathrm{CH}_{3} \mathrm{CO}\right), 23.1\left(\mathrm{CH}_{2}, \mathrm{C}-11^{\prime}\right), 25.9\left(\mathrm{CH}_{3}, \mathrm{C}-15^{\prime}\right), 62.3\left(\mathrm{CH}_{2}, \mathrm{C}-6\right), 65.5\left(\mathrm{CH}_{2}, \mathrm{C}-16^{\prime}\right), 68.0(\mathrm{CH}, \mathrm{C}-4), 70.6$ (CH, C-2), 72.5 (CH, C-5), 73.7 (CH, C-3), 84.3 (CH, C-1), 120.4 (CH, C-12'), 124.4 (CH, C-18'), 126.2 (CH, C-5'), 126.4 (CH, C-8'), 131.6 (C, C-10'), 131.8 (C, C-9'), 133.1 (CH, C-17'), 134.2 (CH, C-6'), 134.6 (CH, C-7'), 135.0 (C, C-13'), 143.7 (C, C-3'), 156.2 (C, C-2'), 168.8-170.4 (C, $\left.\mathrm{COCH}_{3}\right), 181.6$ (CO, C-1 $\left.{ }^{\prime}\right), 185.0\left(\mathrm{CO}, \mathrm{C}^{4} 4^{\prime}\right)$; UPLC purity $=95 \%, \mathrm{tR}=6.84 \mathrm{~min}$; HRMS $\left(\mathrm{ESI}^{+}\right) \mathrm{m} / \mathrm{z}$ calcd for $\mathrm{C}_{32} \mathrm{H}_{36} \mathrm{~N}_{3} \mathrm{O}_{12}$ 654.23, found $655.18\left(\mathrm{M}+\mathrm{H}^{+}\right)$.

\subsubsection{2-[1-(2,3,4,6-tetra-O-acetyl- $\beta$-D-galactopyranosyl)-1,2,3-triazol-4-(methyl)oxy]-3-}

(3-methyl-2-butenyl)-1,4-naphthoquinone (18).

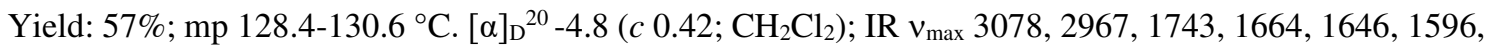
1221, $1043 \mathrm{~cm}^{-1} ;{ }^{1} \mathrm{H}$ NMR ( $\left.\mathrm{CDCl}_{3}, 400 \mathrm{MHz}\right) \delta 1.66\left(3 \mathrm{H}, \mathrm{s}, \mathrm{CH}_{3}, \mathrm{H}-15^{\prime}\right), 1.72\left(3 \mathrm{H}, \mathrm{s}, \mathrm{CH}_{3}, \mathrm{H}-14\right.$ '), 1.79-2.22 (12H, s, $\left.\mathrm{CH}_{3}, \mathrm{C}_{3} \mathrm{CO}\right), 3.25$ (2H, d, $J=7.2 \mathrm{~Hz}, \mathrm{H}-11$ '), 4.10-4.24 (3H, m, H-5 and H-6), 5.06 $\left(1 \mathrm{H}, \mathrm{t}, J=7.1 \mathrm{~Hz}, \mathrm{H}-12^{\prime}\right), 5.24$ (1H, dd, $\left.J=3.2,10.3 \mathrm{~Hz}, \mathrm{H}-3\right), 5.53(1 \mathrm{H}, \mathrm{t}, J=9.5 \mathrm{~Hz}, \mathrm{H}-2), 5.55(1 \mathrm{H}, \mathrm{d}, J$ = 3.4 Hz, H-4), $5.58\left(2 \mathrm{H}, \mathrm{br}, \mathrm{H}-16^{\prime}\right), 5.83(1 \mathrm{H}, \mathrm{d}, J=9.3 \mathrm{~Hz}, \mathrm{H}-1), 7.69-7.71\left(2 \mathrm{H}, \mathrm{m}, \mathrm{H}-6\right.$ ' and $\left.\mathrm{H}-7^{\prime}\right), 7.98$ 
$\left(1 \mathrm{H}, \mathrm{s}, \mathrm{H}-18^{\prime}\right), 8.06\left(1 \mathrm{H}, \mathrm{d}, J=4.8 \mathrm{~Hz}, \mathrm{H}-5^{\prime}\right), 8.08\left(1 \mathrm{H}, \mathrm{d}, J=4.8 \mathrm{~Hz}, \mathrm{H}-8^{\prime}\right) ;{ }^{13} \mathrm{C} \mathrm{NMR}\left(\mathrm{CDCl}_{3}, 100 \mathrm{MHz}\right)$ $\delta 17.9\left(\mathrm{CH}_{3}, \mathrm{C}-14^{\prime}\right), 20.0-20.6\left(\mathrm{CH}_{3}, \underline{\left.\mathrm{CH}_{3} \mathrm{CO}\right)}\right) 23.2\left(\mathrm{CH}_{2}, \mathrm{C}-11^{\prime}\right), 25.8\left(\mathrm{CH}_{3}, \mathrm{C}-15^{\prime}\right), 61.2\left(\mathrm{CH}_{2}, \mathrm{C}-6\right), 65.8$ $\left(\mathrm{CH}_{2}, \mathrm{C}-16\right.$ ') $, 66.9(\mathrm{CH}, \mathrm{C}-5), 67.8(\mathrm{CH}, \mathrm{C}-4), 70.7(\mathrm{CH}, \mathrm{C}-3), 74.2(\mathrm{CH}, \mathrm{C}-2), 86.4(\mathrm{CH}, \mathrm{C}-1), 118.9(\mathrm{CH}$, C-12'), 122.0 (CH, C-18'), 126.2 (CH, C-5'), 126.3 (CH, C-8'), 131.5 (C, C-10'), 132.1 (C, C-9'), 133.2 (CH, C-6'), 133.7 (C, C-13'), 133.8 (CH, C-7'), 135.9 (C, C-3'), 155.7 (C, C-2'), 168.9-170.3 (C, $\left.\mathrm{COCH}_{3}\right)$, $182.0\left(\mathrm{CO}, \mathrm{C}-1^{\prime}\right), 185.2\left(\mathrm{CO}, \mathrm{C}-4\right.$ '); UPLC purity $>99 \%, \mathrm{tR}=6.79 \mathrm{~min}$; HRMS $\left(\mathrm{ESI}^{+}\right) \mathrm{m} / \mathrm{z}$ calcd for $\mathrm{C}_{32} \mathrm{H}_{36} \mathrm{~N}_{3} \mathrm{O}_{12} 654.23$, found $653.87\left(\mathrm{M}+\mathrm{H}^{+}\right)$.

4.2.3.3 2-[1-(2-acetamido-3,4,6-tri-O-acetyl-2-deoxy- $\beta$-D-glucopyranosyl)-1,2,3-triazol-4-(methyl)oxy]3-(3-methyl-2-butenyl)-1,4-naphthoquinone (19).

Yield: 68\%; mp $218.5-222.1^{\circ} \mathrm{C}$. $[\alpha]_{\mathrm{D}}^{20}-27.5\left(c 0.40 ; \mathrm{CH}_{2} \mathrm{Cl}_{2}\right)$; IR $v_{\max } 3291,2936,1749,1661,1596$, $1534,1213,1190,1039 \mathrm{~cm}^{-1} ;{ }^{1} \mathrm{H}$ NMR (DMSO-d $\left.6,400 \mathrm{MHz}\right) \delta 1.52\left(3 \mathrm{H}, \mathrm{s}, \mathrm{CH}_{3}, \mathrm{H}-15^{\prime}\right), 1.58\left(3 \mathrm{H}, \mathrm{s}, \mathrm{CH}_{3}\right.$, H-14'), 1.60 (3H, s, $\left.\mathrm{CH}_{3}, \mathrm{NHCOCH}_{3}\right), 1.94-2.01\left(9 \mathrm{H}, \mathrm{s}, \mathrm{CH}_{3}, \mathrm{C}_{3} \underline{3} \mathrm{CO}\right), 3.03$ (2H, d, J = 6.8 Hz, H-11'), $4.05(1 \mathrm{H}, \mathrm{d}, J=11.8 \mathrm{~Hz}, \mathrm{H}-6 \mathrm{a}), 4.14(1 \mathrm{H}, \mathrm{dd}, J=4.9,12.3 \mathrm{~Hz}, \mathrm{H}-6 \mathrm{~b}), 4.24(1 \mathrm{H}, \mathrm{dd}, J=2.8,9.8 \mathrm{~Hz}, \mathrm{H}-5)$, $4.61(1 \mathrm{H}, \mathrm{q}, J=9.7 \mathrm{~Hz}, \mathrm{H}-2), 4.95\left(1 \mathrm{H}, \mathrm{t}, J=6.6 \mathrm{~Hz}, \mathrm{H}-12^{\prime}\right), 5.09(1 \mathrm{H}, \mathrm{t}, J=9.7 \mathrm{~Hz}, \mathrm{H}-3), 5.33(1 \mathrm{H}, \mathrm{t}, J=$ $9.8 \mathrm{~Hz}, \mathrm{H}-4), 5.47$ (1H, d, $J=13.0 \mathrm{~Hz}, \mathrm{H}-16$ 'a), 5.51 (1H, d, $J=12.9 \mathrm{~Hz}, \mathrm{H}-16$ 'b), 6.10 (1H, d, $J=9.9 \mathrm{~Hz}$, H-1), 7.83-7.85 (2H, m, H-6' and H-7'), 7.96-7.98 (1H, m, $\left.\mathrm{N}^{\mathrm{HCOCH}}{ }_{\underline{3}}\right), 8.01-8.04$ (2H, m, H-5' and H-8'), $8.41\left(1 \mathrm{H}, \mathrm{s}, \mathrm{H}-18^{\prime}\right) .{ }^{13} \mathrm{C}$ NMR (DMSO- $\left.d_{6}, 100 \mathrm{MHz}\right) \delta 17.6\left(\mathrm{CH}_{3}, \mathrm{C}-14{ }^{\prime}\right), 20.2-22.0\left(\mathrm{CH}_{3}, \mathrm{CH}_{3} \mathrm{CO}\right), 22.6$ $\left(\mathrm{CH}_{2}, \mathrm{C}-11^{\prime}\right), 25.3\left(\mathrm{CH}_{3}, \mathrm{C}-15^{\prime}\right), 52.0\left(\mathrm{CH}_{2}, \mathrm{C}-2\right), 61.8\left(\mathrm{CH}_{2}, \mathrm{C}-6\right), 65.1\left(\mathrm{CH}_{2}, \mathrm{C}-16\right.$ ') $, 68.0(\mathrm{CH}, \mathrm{C}-5), 72.4$ (CH, C-4), 73.3 (CH, C-3), 84.8 (CH, C-1), 119.9 (CH, C-12'), 123.6 (CH, C-18'), 125.7 (CH, C-5'), 125.9 (CH, C-8'), 131.1 (C, C-10'), 131.4 (C, C-9'), 132.5 (CH, C-17'), 133.7 (CH, C-6'), 134.1 (CH, C-7'), 134.4 (C, C-13'), 142.8 (C, C-3'), 155.8 (C, C-2'), 169.2-169.9 (C, $\mathrm{CH}_{3} \underline{\mathrm{CO}}$ ), 181.1 (CO, C-1'), 184.5 (CO, C-4'); UPLC purity $=95 \%, t R=6.10 \mathrm{~min}$; HRMS $\left(\mathrm{ESI}^{+}\right) \mathrm{m} / z$ calcd for $\mathrm{C}_{32} \mathrm{H}_{37} \mathrm{~N}_{4} \mathrm{O}_{11} 653.25$, found 653.02 $\left(\mathrm{M}+\mathrm{H}^{+}\right)$.

4.2.3.4 2-[1-(2,3,4-tri-O-acetyl-6-deoxy- $\beta$-L-galactopyranosyl)-1,2,3-triazol-4-(methyl)oxy]-3-(3-methyl2-butenyl)-1,4-naphthoquinone (20).

Yield: $85 \%$; mp $120.3-124.3{ }^{\circ} \mathrm{C}$. $[\alpha]_{\mathrm{D}}{ }^{20}+2.5$ (c 0.40; acetone). IR $v_{\max } 3082,2936,1745,1665,1612$, 1596, 1251, 1191, 1045, $1020 \mathrm{~cm}^{-1} ;{ }^{1} \mathrm{H}$ NMR $\left(\mathrm{CDCl}_{3}, 400 \mathrm{MHz}\right) \delta 1.26\left(3 \mathrm{H}, \mathrm{d}, J=8.0 \mathrm{~Hz}, \mathrm{CH}_{3}, \mathrm{H}-6\right), 1.67$ (3H, s, $\left.\mathrm{CH}_{3}, \mathrm{H}-15^{\prime}\right), 1.72\left(3 \mathrm{H}, \mathrm{s}, \mathrm{CH}_{3}, \mathrm{H}-14^{\prime}\right), 1.79-2.24\left(9 \mathrm{H}, \mathrm{s}, \mathrm{CH}_{3}, \mathrm{CH}_{3} \mathrm{CO}\right), 3.24(2 \mathrm{H}, \mathrm{d}, J=4.0 \mathrm{~Hz}, \mathrm{H}-$ 
$\left.11^{\prime}\right), 4.12(1 \mathrm{H}, \mathrm{q}, J=8.0 \mathrm{~Hz}, \mathrm{H}-5), 5.10(1 \mathrm{H}, \mathrm{t}, J=7.2 \mathrm{~Hz}, \mathrm{H}-12$ '), $5.28(1 \mathrm{H}, \mathrm{dd}, J=3.2,10.2 \mathrm{~Hz}, \mathrm{H}-3)$, $5.44(1 \mathrm{H}, \mathrm{t}, J=3.2 \mathrm{~Hz}, \mathrm{H}-4), 5.54(1 \mathrm{H}, \mathrm{q}, J=9.6 \mathrm{~Hz}, \mathrm{H}-2), 5.63(1 \mathrm{H}, \mathrm{br}, \mathrm{H}-16$ ') $5.85(1 \mathrm{H}, \mathrm{d}, J=9.2 \mathrm{~Hz}$, H-1), 7.68-7.72 (2H, m, H-6' and H-7'), 8.00 (1H, s, H-18'), 8.05-8.09 (2H, m, H-5' and H-8'); ${ }^{13} \mathrm{C}$ NMR $\left(\mathrm{CDCl}_{3}, 100 \mathrm{MHz}\right) \delta 16.0\left(\mathrm{CH}_{3}, \mathrm{C}-6\right), 17.9\left(\mathrm{CH}_{3}, \mathrm{C}-14{ }^{\prime}\right), 20.1-20.7\left(\mathrm{CH}_{3}, \underline{\mathrm{C}} \mathrm{H}_{3} \mathrm{CO}\right), 23.2\left(\mathrm{CH}_{2}, \mathrm{C}-11^{\prime}\right)$, $25.8\left(\mathrm{CH}_{3}, \mathrm{C}-15^{\prime}\right), 65.8\left(\mathrm{CH}_{2}, \mathrm{C}-16\right.$ ') $67.9(\mathrm{CH}, \mathrm{C}-5), 69.9\left(\mathrm{CH}_{2}, \mathrm{C}-2\right), 71.2(\mathrm{CH}, \mathrm{C}-4), 72.8(\mathrm{CH}, \mathrm{C}-3)$, 86.5 (CH, C-1), 119.9 (CH, C-12'), 126.2 (CH, C-5' and C-8'), 131.5 (C, C-10'), 132.1 (C, C-9'), 133.2 (CH, C-6'), 133.7 (CH, C-7'), 133.8 (C, C-13'), 135.8 (C, C-3'), 155.8 (C, C-2'), 169.0-170.3 (C, $\left.\mathrm{CH}_{3} \mathrm{CO}\right)$, $181.9\left(\mathrm{CO}, \mathrm{C}^{\prime} 1^{\prime}\right), 184.2\left(\mathrm{CO}, \mathrm{C}-4\right.$ ') ; UPLC purity $=96 \%, \mathrm{tR}=6.89 \mathrm{~min}$; HRMS $\left(\mathrm{ESI}^{+}\right) \mathrm{m} / z$ calcd for $\mathrm{C}_{30} \mathrm{H}_{34} \mathrm{~N}_{3} \mathrm{O}_{10} 596.22$, found $595.79\left(\mathrm{M}+\mathrm{H}^{+}\right)$.

\subsubsection{2-[1-(B-D-glucopyranosyl)-1,2,3-triazol-4-(methyl)oxy]-3-(3-methyl-2-butenyl)-1,4-naphtho- quinone (21).}

Yield: 59\%; mp $118.5-120.7^{\circ} \mathrm{C} .[\alpha]_{\mathrm{D}}^{20}-15.8(c 0.38 ; \mathrm{MeOH})$; IR $v_{\max } 3282,2912,1652,1593,1092,1047$ $\mathrm{cm}^{-1} ;{ }^{1} \mathrm{H}$ NMR (DMSO- $\left.d_{6}, 400 \mathrm{MHz}\right) \delta 1.60\left(3 \mathrm{H}, \mathrm{s}, \mathrm{CH}_{3}, \mathrm{H}-15^{\prime}\right), 1.64\left(3 \mathrm{H}, \mathrm{s}, \mathrm{CH}_{3}, \mathrm{H}-14\right.$ '), $3.11(2 \mathrm{H}, \mathrm{d}, J$ $\left.=7.2 \mathrm{~Hz}, \mathrm{H}-11^{\prime}\right), 3.21-3.47(4 \mathrm{H}, \mathrm{m}, \mathrm{H}-3, \mathrm{H}-4$ and $\mathrm{H}-6), 3.68-3.78(2 \mathrm{H}, \mathrm{m}, \mathrm{H}-2$ and $\mathrm{H}-5), 4.58(1 \mathrm{H}, \mathrm{t}, J=$ $5.2 \mathrm{~Hz}, \mathrm{OH}), 4.99\left(1 \mathrm{H}, \mathrm{t}, J=7.2 \mathrm{~Hz}, \mathrm{H}-12^{\prime}\right), 5.13(1 \mathrm{H}, \mathrm{d}, J=5.6 \mathrm{~Hz}, \mathrm{OH}), 5.25(1 \mathrm{H}, \mathrm{d}, J=4.8 \mathrm{~Hz}, \mathrm{OH})$, $5.34(1 \mathrm{H}, \mathrm{d}, J=6.4 \mathrm{~Hz}, \mathrm{OH}), 5.46(2 \mathrm{H}, \mathrm{s}, \mathrm{H}-16$ '), $5.55(1 \mathrm{H}, \mathrm{d}, J=9.2 \mathrm{~Hz}, \mathrm{H}-1), 7.83-7.87$ (2H, m, H-6' and $\left.\mathrm{H}-7^{\prime}\right), 7.96-8.04$ (2H, m, H-5' and H-8'), 8.42 (1H, s, H-18'); ${ }^{13} \mathrm{C}$ NMR (DMSO- $\left.d_{6}, 100 \mathrm{MHz}\right) \delta 17.7$ $\left(\mathrm{CH}_{3}, \mathrm{C}-14^{\prime}\right), 22.6\left(\mathrm{CH}_{2}, \mathrm{C}-11^{\prime}\right), 25.4\left(\mathrm{CH}_{3}, \mathrm{C}-15^{\prime}\right), 60.6\left(\mathrm{CH}_{2}, \mathrm{C}-6\right), 65.5\left(\mathrm{CH}_{2}, \mathrm{C}-16^{\prime}\right), 69.5(\mathrm{CH}, \mathrm{C}-4)$, 72.0 (CH, C-2), 76.9 (CH, C-5), 79.9 (CH, C-3), 87.4 (CH, C-1), 120.0 (CH, C-12'), 123.9 (CH, C-18'), 125.6 (CH, C-5'), 125.9 (CH, C-8'), 131.1 (C, C-10'), 131.3 (C, C-9'), 132.6 (CH, C-17'), 133.7 (CH, C6’), 134.1 (CH, C-7'), 134.1 (C, C-13'), 142.5 (C, C-3'), 156.2 (C, C-2'), 181.0 (CO, C-1'), 184.6 (CO, C4'); UPLC purity $>99 \%, t R=4.53 \mathrm{~min}$; HRMS $\left(\mathrm{ESI}^{+}\right) \mathrm{m} / z$ calcd for $\mathrm{C}_{24} \mathrm{H}_{28} \mathrm{~N}_{3} \mathrm{O}_{8} 486.19$, found 485.84 $\left(\mathrm{M}+\mathrm{H}^{+}\right)$

\subsubsection{2-[1-( $\beta$-D-galactopyranosyl)-1,2,3-triazol-4-(methyl)oxy]-3-(3-methyl-2-butenyl)-1,4- naphthoquinone (22).}

Yield: 51\%; mp $182.5-187.2^{\circ} \mathrm{C} .[\alpha]_{D}{ }^{20}-8.0(c 1.00 ; \mathrm{MeOH})$; IR $v_{\max } 3282,2912,1652,1593,1092,1047$ $\mathrm{cm}^{-1} ;{ }^{1} \mathrm{H}$ NMR (DMSO- $d_{6} /$ acetone- $\left.d_{6}, 400 \mathrm{MHz}\right) \delta 1.63\left(3 \mathrm{H}, \mathrm{s}, \mathrm{CH}_{3}, \mathrm{H}-15^{\prime}\right), 1.69\left(3 \mathrm{H}, \mathrm{s}, \mathrm{CH}_{3}, \mathrm{H}-14^{\prime}\right), 3.19$ $\left(2 \mathrm{H}, \mathrm{d}, J=7.4 \mathrm{~Hz}, \mathrm{H}-11^{\prime}\right), 3.59-3.70(3 \mathrm{H}, \mathrm{m}, \mathrm{H}-3$ and H-6), $3.81(1 \mathrm{H}, \mathrm{t}, J=6.0 \mathrm{~Hz}, \mathrm{H}-5), 3.95(1 \mathrm{H}, \mathrm{t}, J=$ 
$3.1 \mathrm{~Hz}, \mathrm{H}-4), 4.16-4.22(1 \mathrm{H}, \mathrm{m}, \mathrm{H}-2), 4.48-4.51(1 \mathrm{H}, \mathrm{m}, \mathrm{OH}), 4.79(1 \mathrm{H}, \mathrm{d}, J=5.8 \mathrm{~Hz}, \mathrm{OH}), 5.04(1 \mathrm{H}, \mathrm{t}, J$ $\left.=6.9 \mathrm{~Hz}, \mathrm{H}-12^{\prime}\right), 5.08(1 \mathrm{H}, \mathrm{d}, J=5.7 \mathrm{~Hz}, \mathrm{OH}), 5.56\left(2 \mathrm{H}, \mathrm{s}, \mathrm{H}-16^{\prime}\right), 5.59(1 \mathrm{H}, \mathrm{d}, J=9.2 \mathrm{~Hz}, \mathrm{H}-1), 7.84-$ $7.86\left(2 \mathrm{H}, \mathrm{m}, \mathrm{H}-6^{\prime}\right.$ and $\left.\mathrm{H}-7^{\prime}\right), 8.02-8.10$ (2H, m, H-5' and H-8'), 8.39 (1H, s, H-18'); ${ }^{13} \mathrm{C}$ NMR (DMSO$d_{6} /$ acetone- $\left.d_{6}, 100 \mathrm{MHz}\right) \delta 18.1\left(\mathrm{CH}_{3}, \mathrm{C}-14^{\prime}\right), 23.5\left(\mathrm{CH}_{2}, \mathrm{C}-11^{\prime}\right), 25.8\left(\mathrm{CH}_{3}, \mathrm{C}-15^{\prime}\right), 61.4\left(\mathrm{CH}_{2}, \mathrm{C}-6\right), 66.6$ ( $\mathrm{CH}_{2}, \mathrm{C}-16$ ') $, 69.4(\mathrm{CH}, \mathrm{C}-5), 70.8(\mathrm{CH}, \mathrm{C}-4), 75.1(\mathrm{CH}, \mathrm{C}-3), 79.4(\mathrm{CH}, \mathrm{C}-2), 89.3(\mathrm{CH}, \mathrm{C}-1), 120.9(\mathrm{CH}$, C-12'), 124.1 (CH, C-18'), 126.5 (CH, C-5'), 126.7 (CH, C-8'), 132.2 (C, C-10'), 132.6 (C, C-9'), 133.6 (CH, C-17'), 134.3 (CH, C-6'), 134.7 (CH, C-7'), 134.7 (C, C-13'), 135.6 (C, C-3'), 157.2 (C, C-2'), 182.2 (CO, C-1'), 185.5 (CO, C-4'); UPLC purity $>99 \%, t R=4.47 \mathrm{~min}$; HRMS (ESI $\left.{ }^{+}\right) \mathrm{m} / z$ calcd for $\mathrm{C}_{24} \mathrm{H}_{28} \mathrm{~N}_{3} \mathrm{O}_{8}$ 486.19, found $485.84\left(\mathrm{M}+\mathrm{H}^{+}\right)$.

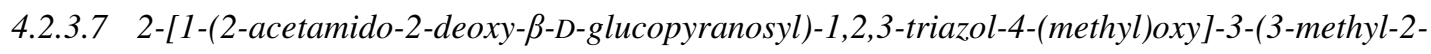
butenyl)-1,4-naphthoquinone (23).

Yield: 55\%; mp $174.9-178.5{ }^{\circ} \mathrm{C}$. $[\alpha]_{\mathrm{D}}{ }^{20}-16.0$ (c 0.50; MeOH); IR $v_{\max } 3485,3282,2919,1655,1593$, $1533,1085,1049 \mathrm{~cm}^{-1} ;{ }^{1} \mathrm{H}$ NMR (DMSO- $d_{6} /$ acetone- $\left.d_{6}, 400 \mathrm{MHz}\right) \delta 1.59\left(3 \mathrm{H}, \mathrm{s}, \mathrm{CH}_{3}, \mathrm{H}-15\right.$ '), $1.63(3 \mathrm{H}$, s, $\mathrm{CH}_{3}, \mathrm{H}-14$ ') 1.70 (3H, s, $\left.\mathrm{CH}_{3}, \mathrm{NHCOC}_{3}\right)$, 3.45-3.82 (7H, m, H-3, H-4, H-5, H-6 and H-11'), 4.20 (1H, q, $J=5.6 \mathrm{~Hz}, \mathrm{H}-2), 4.33(1 \mathrm{H}, \mathrm{t}, J=5.7 \mathrm{~Hz}, \mathrm{OH}), 5.04-5.05(3 \mathrm{H}, \mathrm{m}, \mathrm{H}-12$ 'and $\mathrm{OH}), 5.56(1 \mathrm{H}, \mathrm{d}, J=12.4$ Hz, H-16'a), 5.60 (1H, d, $J=12.3 \mathrm{~Hz}, \mathrm{H}-16$ 'b), $5.80(1 \mathrm{H}, \mathrm{d}, J=10.0 \mathrm{~Hz}, \mathrm{H}-1), 7.68(1 \mathrm{H}, \mathrm{d}, J=9.2 \mathrm{~Hz}$, $\left.\mathrm{NHCOCH}_{3}\right), 7.82-7.85\left(2 \mathrm{H}, \mathrm{m}, \mathrm{H}-6\right.$ ' and $\left.\mathrm{H}-7^{\prime}\right), 8.01-8.09$ (2H, m, H-5' and $\left.\mathrm{H}-8^{\prime}\right), 8.25\left(1 \mathrm{H}, \mathrm{s}, \mathrm{H}-18^{\prime}\right) ;{ }^{13} \mathrm{C}$ NMR (DMSO- $d_{6} /$ acetone- $\left.d_{6}, 100 \mathrm{MHz}\right) \delta 18.1\left(\mathrm{CH}_{3}, \mathrm{C}-14^{\prime}\right), 22.8\left(\mathrm{CH}_{3}, \mathrm{NHCOCH}_{3}\right), 23.6\left(\mathrm{CH}_{2}, \mathrm{C}-11^{\prime}\right)$, $25.9\left(\mathrm{CH}_{3}, \mathrm{C}-15\right.$ ') $, 55.5(\mathrm{CH}, \mathrm{C}-2), 62.0\left(\mathrm{CH}_{2}, \mathrm{C}-6\right), 66.2\left(\mathrm{CH}_{2}, \mathrm{C}-16\right.$ '), $71.2(\mathrm{CH}, \mathrm{C}-5), 75.2(\mathrm{CH}, \mathrm{C}-4)$, 81.0 (CH, C-3), 87.5 (CH, C-1), 121.0 (CH, C-12'), 124.0 (CH, C-18'), 126.5 (CH, C-5'), 126.7 (CH, C8'), 132.4 (C, C-10'), 132.7 (C, C-9'), 133.5 (CH, C-17'), 134.2 (CH, C-6'), 134.6 (CH, C-7'), 134.6 (C, C-13'), 135.8 (C, C-3'), 156.8 (C, C-2'), 170.1 (C, $\left.\mathrm{NHCOCH}_{3}\right), 182.3$ (CO, C-1'), 185.5 (CO, C-4'); UPLC purity $>99 \%, \mathrm{tR}=4.52 \mathrm{~min}$; HRMS $\left(\mathrm{ESI}^{+}\right) \mathrm{m} / z$ calcd for $\mathrm{C}_{26} \mathrm{H}_{31} \mathrm{~N}_{4} \mathrm{O}_{8} 527.21$, found $527.00\left(\mathrm{M}+\mathrm{H}^{+}\right)$.

\subsubsection{2-[1-(6-deoxy- $\beta$-L-galactopyranosyl)-1,2,3-triazol-4-(methyl)oxy]-3-(3-methyl-2-butenyl)- 1,4-naphthoquinone (24).}

Yield: 47\%; mp 91.0-94.0 ${ }^{\circ} \mathrm{C}$. $[\alpha]_{\mathrm{D}}{ }^{20}+15.8\left(c 0.38\right.$; acetone); IR $v_{\max } 3357,2926,1666,1090 \mathrm{~cm}^{-1} ;{ }^{1} \mathrm{H}$ NMR (acetone- $\left.d_{6}, 400 \mathrm{MHz}\right) \delta 1.26\left(3 \mathrm{H}, \mathrm{d}, J=4.0 \mathrm{~Hz}, \mathrm{CH}_{3}, \mathrm{H}-6\right), 1.62\left(3 \mathrm{H}, \mathrm{s}, \mathrm{CH}_{3}, \mathrm{H}-15^{\prime}\right), 1.68\left(3 \mathrm{H}, \mathrm{s}, \mathrm{CH}_{3}\right.$, H-14'), 3.20 (2H, d, J = 8.0 Hz, H-11'), 3.76-3.79 (2H, m, H-3 and H-4), 3.95-4.03 (1H, m, H-2), $4.01(1 \mathrm{H}$, 
q, $J=4.0 \mathrm{~Hz}, \mathrm{H}-5), 4.19-4.23(2 \mathrm{H}, \mathrm{m}, \mathrm{OH}), 4.46(1 \mathrm{H}, \mathrm{d}, J=4.0 \mathrm{~Hz}, \mathrm{OH}), 5.03(1 \mathrm{H}, \mathrm{d}, J=8.0 \mathrm{~Hz}, \mathrm{H}-12$ '), $5.57\left(2 \mathrm{H}, \mathrm{s}, \mathrm{H}-16^{\prime}\right), 5.58(1 \mathrm{H}, \mathrm{d}, J=8.0 \mathrm{~Hz}, \mathrm{H}-1), 7.81-7.84\left(2 \mathrm{H}, \mathrm{m}, \mathrm{H}-6^{\prime}\right.$ and H-7'), 8.01-8.04 (2H, m, H5' and H-8'), 8.25 (1H, s, H-18'); ${ }^{13} \mathrm{C}^{\prime} \mathrm{NMR}$ (acetone- $\left.d_{6}, 100 \mathrm{MHz}\right): 15.9\left(\mathrm{CH}_{3}, \mathrm{C}-6\right), 17.2\left(\mathrm{CH}_{3}, \mathrm{C}-14\right.$ '), $22.8\left(\mathrm{CH}_{2}, \mathrm{C}-11^{\prime}\right), 24.9\left(\mathrm{CH}_{3}, \mathrm{C}-15^{\prime}\right), 65.8\left(\mathrm{CH}_{2}, \mathrm{C}-16^{\prime}\right), 70.1(\mathrm{CH}, \mathrm{C}-5), 71.5(\mathrm{CH}, \mathrm{C}-2), 73.6(\mathrm{CH}, \mathrm{C}-4)$, 74.5 (CH, C-3), 88.4 (CH, C-1), 120.2 (CH, C-12'), 122.8 (CH, C-18'), 125.8 (CH, C-5’), 125.9 (CH, C8'), 131.7 (C, C-10'), 132.0 (C, C-9'), 132.8 (CH, C-17'), 133.4 (CH, C-6'), 133.9 (CH, C-7'), 133.9 (C, C-13'), 135.0 (C, C-3'), 156.4 (C, C-2'), 181.5 (CO, C-1'), 184.7 (CO, C-4'); UPLC purity >99\%, tR = 5.01 min; HRMS (ESI $\left.{ }^{+}\right) \mathrm{m} / z$ calcd for $\mathrm{C}_{24} \mathrm{H}_{28} \mathrm{~N}_{3} \mathrm{O}_{7} 470.19$, found: $470.32\left(\mathrm{M}+\mathrm{H}^{+}\right)$.

\subsection{UPLC/MS analysis of lapachol derivatives}

All final compounds were purified to $>95 \%$ purity, as determined by UPLC/MS analyses, carried out using an ACQUITY Ultra Performance LCTM system (Waters, Milford, MA, USA) linked simultaneously to both a PDA 2996 photodiode array detector (Waters, Milford, MA, USA) and an ACQUITY TQ Detector (Waters MS Technologies, Manchester, UK), equipped with a Z-spray electrospray ionization (ESI) source operating in positive mode. MassLynx ${ }^{\mathrm{TM}}$ software (version 4.1, Waters, Milford, MA, USA) was used to control the instruments, as well as for data acquisition and processing. Sample solutions ( $3 \mu \mathrm{L} ; 0.5 \mathrm{mg} / \mathrm{mL}$ ) were injected into a reversed phase column $\left(\mathrm{BEH}_{\mathrm{C} 18}\right.$, $1.7 \mu \mathrm{m}, 1 \times 50 \mathrm{~mm}$, Waters, Milford, MA), which was maintained at $40^{\circ} \mathrm{C}$. The mobile phase consisted of solvent $\mathrm{A}\left(\mathrm{H}_{2} \mathrm{O} / 0.1 \mathrm{HCOOH}\right)$ and solvent B (acetonitrile/0.1 HCOOH) at a flow rate of $300 \mu \mathrm{L} / \mathrm{min}$ : $\mathrm{T}=0$ $\min , 5 \% \mathrm{~B} ; \mathrm{T}=10 \mathrm{~min}, 95 \% \mathrm{~B} ; \mathrm{T}=11 \mathrm{~min}, 5 \% \mathrm{~B} ; \mathrm{T}=13 \mathrm{~min}, 5 \% \mathrm{~B}$. The effluent was introduced into a PDA detector (scanning range $210-400 \mathrm{~nm}$, resolution $1.2 \mathrm{~nm}$ ) and subsequently into an electrospray source (source block temperature $120^{\circ} \mathrm{C}$, desolvation temperature $350^{\circ} \mathrm{C}$, capillary voltage $3.5 \mathrm{kV}$, cone voltage $30 \mathrm{~V})$ and nitrogen was used as the desolvation gas $(600 \mathrm{~L} / \mathrm{h})$. Mass chromatograms were recorded in the positive and negative ionization mode in the range from 100-1300 Da.

\subsection{Infrared spectroscopy}

IR spectrum was recorded on a Spectrum One, Perkin-Elmer ATR system. 
4.6 NMR analysis

${ }^{1} \mathrm{H}$ NMR, ${ }^{13} \mathrm{C}$ NMR, DEPT-135, ${ }^{1} \mathrm{H}-{ }^{1} \mathrm{H}$ COSY, HSQC and HMBC spectra were recorded on Bruker Avance DRX-400 $\left({ }^{1} \mathrm{H} 400 \mathrm{MHz}\right.$ and $\left.{ }^{13} \mathrm{C} 100 \mathrm{MHz}\right)$ in acetone- $\mathrm{d}_{6}, \mathrm{CDCl}_{3}$ and DMSO- $\mathrm{d}_{6}$ at $300 \mathrm{~K}$ using TMS as internal standard for both nuclei. Chemical shifts $(\delta)$ are given in ppm and $J$ couplings in Hertz (Hz).

\subsection{Cytotoxicity measurements}

\subsubsection{Cell lines and culture}

Human acute promyelocytic leukemia cells (HL60), human acute T cells leukemia (Jurkat) and human monocytic leukemia cells (THP-1) were kindly donated by Prof. Gustavo P Amarante Mendes (University of São Paulo/Brazil). Human breast cancer (MCF-7 and MDA-MB-231) and colorectal lineages (HCT-116) were gently donated by Prof. Marcel Leist (University of Konstanz/Germany). Leukemia cells were cultivated in RPMI 1640 medium (Sigma-Aldrich, St. Louis, MO), supplemented with $100 \mathrm{U} / \mathrm{mL}$ penicillin and $100 \mu \mathrm{g} / \mathrm{mL}$ streptomycin (GIBCO BRL, Grand Island, NY), enriched with $2 \mathrm{mM}$ of Lglutamine (GIBCO UK, Grand Island, NY) and 10\% fetal bovine serum. Breast cancer and colorectal lineages were cultivated in DMEM medium (Sigma-Aldrich, St. Louis, MO), supplemented with $100 \mathrm{U} / \mathrm{mL}$ penicillin, $100 \mu \mathrm{g} / \mathrm{mL}$ streptomycin (GIBCO BRL, Grand Island, NY), enriched with 10\% fetal bovine serum (GIBCO BRL, Grand Island, NY). All cultures were maintained at $37{ }^{\circ} \mathrm{C}$ in a humidified incubator with $5 \% \mathrm{CO}_{2}$. Cells were splited twice a week and routinely evaluated for contamination.

4.7.2. Cytotoxic of lapachol and glycosides against HL60, Jurkat, THP-1, MDA-MB-231, MCF-7 and HCT-116 cells

Cell viability was detected by the rate of the mitochondrial reduction of the yellow tetrazolium salt MTT (3-(4,5-dimethylthiazol-2-yl)-2,5-diphenyltetrazolium bromide (Sigma-Aldrich, St. Louis, MO) into insoluble purple formazan crystals, and the color intensity of the formazan dye is correlated with the number

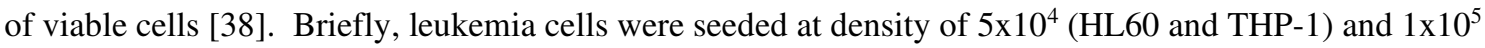
(Jurkat). MCF-7, MDA-MB-231 and HCT-116 cells were seeded at 1x10 cells/well, in 96-well plates. The plates were pre-incubated in a $95 \%$ air-humidified atmosphere with a $5 \% \mathrm{CO}_{2}$ for $24 \mathrm{~h}$ at $37^{\circ} \mathrm{C}$ to allow for the adaptation of cells. The compounds were tested over a two-fold serial dilution concentration (100- 
$0.78 \mu \mathrm{M})$. The cells cultures were incubated for an additional $48 \mathrm{~h}$ at $37^{\circ} \mathrm{C}$ with the compounds. DMSO at $0.5 \%$ was used as negative control (solvent control). After incubation, $20 \mu \mathrm{L}$ MTT solution $(2.5 \mathrm{mg} / \mathrm{mL}$ ) were added in each well followed by $4 \mathrm{~h}$ incubation. The supernatant was removed, and $200 \mu \mathrm{L}$ of $0.04 \mathrm{M}$ $\mathrm{HCl}$ in isopropyl alcohol was added. The optical densities (OD) were measured at $595 \mathrm{~nm}$ in a plate reader (VarioScan, Thermo Scientific ${ }^{\circledR}$ ). The results were normalized by solvent control (DMSO at $0.5 \%$ ), and half maximal inhibitory concentration $\left(\mathrm{IC}_{50}\right)$ and $\mathrm{IC}_{80}$ values were obtained from concentration-effect curves using Prism 7.0 (GraphPad Software Inc). Etoposide was used as positive control. Three experiments were performed in triplicate.

\subsubsection{Cytotoxic of lapachol and derivates against human peripheral blood mononuclear cells}

\subsubsection{Human peripheral blood mononuclear cells}

Cells obtained from six healthy donors were collected and processed in less than 24h intervals. Protocol for the use of human peripheral blood at COEP number 30860113.1.1001.5149/2016.

\subsubsection{Isolation of human peripheral blood mononuclear cells}

Human peripheral blood mononuclear cells (PBMC) were separated according to the method described by Souza-Fagundes et al (2002), with modifications [63]. Cells were isolated from venous blood collected from six healthy subjects using heparinized tubes. The heparinized blood was gently placed in 50mL Falcon tubes (Pyrex Laboratory Glassware) containing a mixture of Ficoll-diatrizoate (LSMLymphocyte Separation Medium, Organon Teknika Corporation, Durhan) in the ratio of a part of Ficolldiatrizoate to two parts of blood. This preparation was then centrifuged for 40 minutes, $500 \mathrm{~g}$ at $20^{\circ} \mathrm{C}$. After centrifugation, the cells were removed and transferred to a $15 \mathrm{~mL}$ graduated conical tube. Then the cells were washed with RPMI for 7 minutes, $300 \mathrm{~g}$ at $4^{\circ} \mathrm{C}$, three times. Cells were seed at density of $2 \times 10^{5}$ cells/well (96-well plates). Cells were maintained in complete culture medium containing RPMI (GIBCO, UK), supplemented with $10 \% \mathrm{v} / \mathrm{v}$ fetal bovine serum, previously inactivated (Gibco, Brazil), $2 \mathrm{mM} \mathrm{L-}$ Glutamine (1\% v/v) (200 mM stock solution, GIBCO UK, Grand Island, NY), $1 \%$ antibiotic-antimycotic mixture (stock solution $1000 \mathrm{U} / \mathrm{mL}$ penicillin, $1000 \mu \mathrm{g} / \mathrm{mL}$ streptomycin and $25 \mu \mathrm{g} / \mathrm{mL}$ fungizone). After stabilization, all cells were incubated with the substances at two-fold serial dilution concentration (100$0.78 \mu \mathrm{M}$ ) for $48 \mathrm{~h}$ under $5 \% \mathrm{CO} 2$ and $100 \%$ humidity at $37^{\circ} \mathrm{C}$. The cells were incubated for an additional 
$48 \mathrm{~h}$ at $37^{\circ} \mathrm{C}$ with the compounds. DMSO at $0.5 \%$ was used as negative control (solvent control). Cell viability were evaluated by the resazurin method, as described below.

\subsubsection{Evaluation of cell viability of human PBMC by resazurin assay}

The cell viability assay was performed according to O'Brien et al. (2000), with modifications.[40] Resazurin is a blue dye and is weakly fluorescent until it is irreversibly reduced to pink and red fluorescent resorufin. It is used as an oxidation-reduction indicator in cell viability assays and its intensity is proportional to the number of viable cells in a culture (Riss et al., 2000) [64]. Briefly, after 48 hours of incubation with the extracts, $20 \mu \mathrm{L}$ of the resazurin solution at $50 \mu \mathrm{g} / \mathrm{mL}$ per well was added. The plates were incubated in a $\mathrm{CO}_{2}$ incubator at $37^{\circ} \mathrm{C}$ for 3 hours. The fluorescence reading was performed at two wavelengths of excitation 530 and emission of $590 \mathrm{~nm}$ - in a plate reader (VarioScan, Thermo Scientific ${ }^{\circledR}$ ).

The number of viable cells correlates with the percentage of reduction of resazurin and were expressed as percent viability/proliferation as follows:

$\%$ cell viability: (fluorescence of the sample-blank) x100 /(fluorescence solvent control)

A blank of each sample was performed to avoid unspecified reactions of the compounds with resazurin (blank) and the results were analyzed using Prism 7.0 (GraphPad Software Inc).

\subsubsection{Selectivity index (SI) determination}

After determining the $\mathrm{IC}_{50}$ values for tumor (HL60, Jurkat, THP-1, MCF-7, MDA-MB-231 and HCT-116 cells) and non-tumor cells (PBMC), the selectivity index was calculated. Determination of the SI was performed by the ratio between $\mathrm{IC}_{50}$ of $\mathrm{PBMC}$ and $\mathrm{IC}_{50}$ tumor cell [65].

\subsubsection{DNA fragmentation assay (subdiploid DNA content)}

The DNA fragmentation were analyzed according to Marques et al., (2020) [20]. Briefly, the cells (HL60, Jurkat, THP-1, MCF-7, MDA-MB-231 and HCT-116) were seed at density of $2 \times 10^{5}$ cell/well in 24-well plate and incubated overnight. Subsequently, the cells were treated with compounds 5, 14-16, etoposide and lapachol at $50 \mu \mathrm{M}$ ( $\mathrm{IC}_{80}$ value) for 24 hours. After treatment, the cells and the supernatant were collected and centrifuged at $500 \mathrm{rpm}$ for $5 \mathrm{~min}$ in a micro-centrifuge (Denver Instrument Company, USA). The supernatant was discarded and the cells labelled with $300 \mu \mathrm{L}$ of a Hypotonic Fluorochromic 
Solution containing $50 \mu \mathrm{g} / \mathrm{mL}$ propidium iodide and $0.1 \%$ Triton X-100 in $0.1 \%$ sodium citrate. After $2 \mathrm{~h}$ of incubation at $8{ }^{\circ} \mathrm{C}$ the samples were analyzed in flow cytometry (Becton-Dickinson, Mountain View, CA). A total of 10.000 events were acquired using Cell Quest and analyzed using FlowJo 7.6.4 ${ }^{\circledR}$ (Tree Star, Inc.) to calculate the number of cells with fragmented DNA (sub-G0/G1).

\subsubsection{Clonogenic assay}

The MCF-7, MDA-MB-231 and HCT-116 cells were seed in 6-well plates at a density of 400 cells/well. After 6 hours of incubation, cells were treated with the compounds (at their $\mathrm{IC}_{50}$ and $\mathrm{IC}_{80}$ ) or control (DMSO 0.5\%). The cells were incubated with the compounds for 24 hours and then the medium was removed and replaced by supplemented DMEM medium without the compounds [66]. The cells were incubated for another 14 days and after incubation, the colonies were fixed in $70 \%$ alcohol for 15 minutes, stained with crystal violet (30\% in ethanol) for 30 minutes and kept at room temperature overnight for drying. Colonies with 50 or more cells were counted. The survival fraction (ratio between the number of colonies treated with the compounds and the number of colonies counted in the control) were calculated and the results were analyzed by GraphPad Prism 7.0.

\subsubsection{Statistical analysis}

Data are expressed as the means \pm SD (standard deviation). Statistical analysis was conducted using the Prism 7.0 statistical package (GraphPad Software, USA). To ascertain significance, we used a one-way ANOVA with Bonferroni post-test. Statistical significance was considered at a limit of $p<0.05$ from three independent experiments conducted in triplicate.

\section{Acknowledgments}

We acknowledge the Brazilian funding agencies Capes (MEC), CNPq (MCTI) and FAPEMIG for our research fellowships and financial support and by the partnership between Capes/Brazil and the Alexander Von Humboldt Foundation/Germany (Process 99999.008121/ 2014-01).

\section{Conflict of interest}

The authors declare no conflict of interest. 


\section{References}

1. GLOBOCAN. Published 2018. Accessed December 1, 2019. http://globocan.iarc.fr/Default.aspx

2. Hande KR. Etoposide: Four Decades of Development of a Topoisomerase II Inhibitor. Eur J Can. 1998;34(10):1514-21. doi: 10.1016/s0959-8049(98)00228-7.

3. Nerendra Nagar, Rakesh K. Jat, Rajkumar Saharan, Sanjay Verma, Daljeet Sharma K bansal. Podophyllotoxin and Their Glycosidic Derivatives. Pharmacophore. 2011;2(2):124-34.Retrieved from https://pharmacophorejournal.com/storage/models/article/3BymzkNQbdu2EXzSZnFBVdOzelfGII TIJYjcg75HoHqyEq72NDhtXbg2ZYfZ/podophyllotoxin-and-their-glycosidic-derivatives.pdf

4. Epifano F, Genovese S, Fiorito S, Mathieu V, Kiss R. Lapachol and its congeners as anticancer agents: a review. Phytochem Rev. 2014;13(1):37-49. doi: 10.1007/s11101-013-9289-1.

5. Hussain H, Green IR. Lapachol and lapachone analogs: a journey of two decades of patent research (1997-2016). Expert Opin Ther Pat. 2017;27(10):1111-1121. doi: 10.1080/13543776.2017.1339792.

6. Araújo EL, Alencar JRB, Rolim Neto PJ. Lapachol: segurança e eficácia na terapêutica. Rev Bras Farmacogn. 2002;12:57-59. doi: 10.1590/S0102-695X2002000300028.

7. Fieser LF. The alkylation of hydroxynaphthoquinone. III. A synthesis of lapachol. J Am Chem Soc. 1927;49(3):857-64. doi: 10.1021/ja01402a030.

8. Kazantzi G, Malamidou-Xenikaki E, Spyroudis S. Palladium-catalyzed allylation of 2-hydroxy-1, 4naphthoquinone: Application to the preparation of lapachol. SYNLETT. 2007;(3):427-30. doi: 10.1055/s-2007-967947.

9. Eyong KO, Kumar PS, Kuete V, Folefoc GN, Nkengfack EA, Baskaran S. Semisynthesis and antitumoral activity of 2-acetylfuranonaphthoquinone and other naphthoquinone derivatives from lapachol. Bioorganic Med Chem Lett. 2008;18(20):5387-90. doi: 10.1016/j.bmcl.2008.09.053.

10. Xiang $\mathrm{M}, \mathrm{Kim} \mathrm{H}, \mathrm{Ho}$ VT, et al. Gene expression-based discovery of atovaquone as a STAT3 inhibitor and anticancer agent. Blood, J Am Soc Hematol. 2016;128(14):1845-1853. doi: 10.1182/blood2015-07-660506.

11. Santana CF de, Lima OG de, D'albuquerque IL, Lacerda AL, Martins DG. Observações sobre as propriedades antitumorais e toxicológicas do extrato do líber e de alguns componentes do cerne do Pau d'arco (Tabebuia avellanedae). Rev Inst Antib. 1968;8(1/2):89-94.

12. Pereyra CE, Dantas RF, Ferreira SB, Gomes LP, Silva-Jr FP. The diverse mechanisms and anticancer potential of naphthoquinones. Cancer Cell Int. 2019;19(1):1-20. doi: 10.1186/s12935-019-0925-8.

13. da Linardi MCF, de Oliveira MM, Sampaio MRP. A Lapachol Derivative Active against Mouse Lymphocytic Leukemia P-388. J Med Chem. 1975;18(11):1159-61. doi:10.1021/jm00245a027.

14. Fedorov SN, Shubina LK, Kuzmich AS, Polonik SG. Antileukemic properties and structure-activity relationships of O- and S-glycosylated derivatives of juglone and related 1,4-naphthoquinones. Open Glycosci. 2011;4(1):1-5. doi: 10.2174/1875398101104010001.

15. Ottoni FM, Gomes ER, Pádua RM, Oliveira MC, Silva IT, Alves RJ. Synthesis and cytotoxicity evaluation of glycosidic derivatives of lawsone against breast cancer cell lines. Bioorganic Med Chem Lett. 2020;30(2):126817-21. doi:16/j.bmcl.2019.126817. 
16. Bodnár B, Mernyák E, Szabó J, et al. Synthesis and in vitro investigation of potential antiproliferative monosaccharide-D-secoestrone bioconjugates. Bioorganic Med Chem Lett. 2017;27(9):1938-42. doi: 10.1016/j.bmcl.2017.03.029.

17. Da Cruz EHG, Hussene CMB, Dias GG, et al. 1,2,3-Triazole-, arylamino- and thio-substituted 1,4naphthoquinones: Potent antitumor activity, electrochemical aspects, and bioisosteric replacement of C-ring-modified lapachones. Bioorganic Med Chem. 2014;22(5):1608-19. doi:10.1016/j.bmc.2014.01.033.

18. Campos VR, Cunha AC, Silva WA, et al. Synthesis of a new class of naphthoquinone glycoconjugates and evaluation of their potential as antitumoral agents. RSC Adv. 2015;5(116):96222-29. doi: 10.1039/C5RA19192K.

19. Jardim GAM, Reis WJ, Ribeiro MF, et al. On the investigation of hybrid quinones: Synthesis, electrochemical studies and evaluation of trypanocidal activity. RSC Adv. 2015;5(95):78047-60. doi:10.1039/c5ra16213k.

20. Marques LB, Ottoni FM, Pinto MCX, et al. Lapachol acetylglycosylation enhances its cytotoxic and pro-apoptotic activities in HL60 cells. Toxicol Vitr. 2020;65:104772. doi:10.1016/j.tiv.2020.104772.

21. Deng D, Yan N. GLUT, SGLT, and SWEET: Structural and mechanistic investigations of the glucose transporters. Protein Sci. 2016;25(3):546-58. doi: 10.1002/pro.2858.

22. HORTON D. 2-Acetamido-3, 4, 6-tri-O-acetyl-2-deoxy- $\alpha$-d-glucopyranosyl chloride. In: General Carbohydrate Method. Elsevier; 1972:282-5. doi: 10.1016/B978-0-12-746206-6.50056-4.

23. Conchie J, Levvy GA, Marsh CA. Methyl and phenyl glycosides of the common sugars. In: Advances in Carbohydrate Chemistry. Vol 12. Elsevier; 1957; 12:157-87. doi: 10.1016/S0096-5332(08)602088.

24. Šardzík R, Noble GT, Weissenborn MJ, Martin A, Webb SJ, Flitsch SL. Preparation of aminoethyl glycosides for glycoconjugation. Beilstein J Org Chem. 2010;6(1):699-03. doi: 10.3762/bjoc.6.81.

25. Starks CM. Phase-transfer catalysis. I. Heterogeneous reactions involving anion transfer by quaternary ammonium and phosphonium salts. J Am Chem Soc. 1971;93(1):195-9. doi: 10.1021/ja00730a033.

26. Lucchese AM, Marzorati L. Catálise de transferência de fase. Quim Nova. 2000;23(5):641-52. doi: 10.1590/S0100-404220000.

27. Ngameni B, Patnam R, Sonna P, Ngadjui BT, Roy R, Abegaz BM. Hemisynthesis and spectroscopic characterization of three glycosylated 4-hydrocylonchocarpins from Dorstenia barteri Bureau. Arkivoc. 2008;2008(6):152-9. doi:10.3998/ark.5550190.0009.614.

28. Rostovtsev V V, Green LG, Fokin V V. A Stepwise Huisgen Cycloaddition Process: Copper(I)Catalyzed Regioselective "Ligation" of Azides and Terminal Alkynes - Rostovtsev - 2002 Angewandte Chemie - Wiley Online Library. Angew Chemie. 2002;(14):2708-11. doi:10.1002/1521-3773(20020715)41:14<2596::AID-ANIE2596>3.0.CO;2-4.

29. Deobald AM, Camargo LRS, Hörner M, Rodrigues OED, Alves D, Braga AL. Synthesis of arylseleno1,2,3-triazoles via copper-catalyzed 1,3-dipolar cycloaddition of azido arylselenides with alkynes. Synthesis (Stuttg). 2011;(15):2397-406. doi:10.1055/s-0030-1260083.

30. Okafor IS, Wang G. Synthesis and gelation property of a series of disaccharide triazole derivatives. Carbohydr Res. 2017;451:81-94. doi:10.1016/j.carres.2017.09.008. 
31. Tang $\mathrm{Y}$, Zhang $\mathrm{S}$, Chang $\mathrm{Y}$, et al. Aglycone Ebselen and $\beta$-d-Xyloside Primed Glycosaminoglycans Co-contribute to Ebselen $\beta$-d-Xyloside-Induced Cytotoxicity. J Med Chem. 2018;61(7):2937-48. doi: 10.1021/acs.jmedchem.7b01835.

32. Kim WG, Kang ME, Lee J Bin, et al. Nickel-catalyzed azide-alkyne cycloaddition to access 1, 5disubstituted 1, 2, 3-triazoles in air and water. J Am Chem Soc. 2017;139(35):12121-4. doi: 10.1021/jacs.7b06338.

33. $\mathrm{Xu} \mathrm{W}$, Yang $\mathrm{H}$, Liu $\mathrm{Y}$, et al. Facile Approaches to 2-Deoxy-d-glucose and 2-Deoxy- $\alpha$-dglucopyranonucleosides from d-Glucal. Synthesis (Stuttg). 2017;49(16):3686-91. doi: 10.1055/s0036-1589501.

34. Zemplén G, Pacsu E. Über die Verseifung acetylierter Zucker und verwandter Substanzen. Berichte der Dtsch Chem Gesellschaft (A B) Ser. 1929;62(6):1613-4. doi: 10.1002/cber.19290620640.

35. Ibatullin FM, Shabalin KA. A simple and convenient synthesis of glycosyl azides. Synth Commun. 2000;30(15):2819-23. doi: 10.1080/00397910008086908.

36. Karplus M. Vicinal proton coupling in nuclear magnetic resonance. I Am Chem Soc. 1963;85(18):2870-1. doi: 10.1021/ja00901a059.

37. Juaristi E, Cuevas G. The Anomeric Effect. CRC press; 1994.

38. Mosmann T. Rapid colorimetric assay for cellular growth and survival: application to proliferation and cytotoxicity assays. J Immunol Methods. 1983;65(1-2):55-63. doi: 10.1016/00221759(83)90303-4.

39. Monks A, Scudiero D, Skehan $P$, et al. Feasibility of a high-flux anticancer drug screen using a diverse panel of cultured human tumor cell lines. JNCI J Natl Cancer Inst. 1991;83(11):757-66. doi: 10.1093/jnci/83.11.757.

40. O'brien J, Wilson I, Orton T, Pognan F. Investigation of the Alamar Blue (resazurin) fluorescent dye for the assessment of mammalian cell cytotoxicity. Eur J Biochem. 2000;267(17):5421-6. doi: 10.1046/j.1432-1327.2000.01606.x.

41. Sittampalam G, Gal-Edd N, Arkin M, Auld D, Austin C. Assay Guidance Manual. Bethesda (MD); Eli Lilly \& Company and the National Center for Advancing Translational Sciences. Published online 2004.

42. Neve RM, Chin K, Fridlyand J, et al. A collection of breast cancer cell lines for the study of functionally distinct cancer subtypes. Cancer Cell. 2006;10(6):515-27. doi: 10.1016/j.ccr.2006.10.008.

43. Lacroix M, Leclercq G. Relevance of breast cancer cell lines as models for breast tumours: an update. Breast Cancer Res Treat. 2004;83(3):249-89. doi: 10.1023/B:BREA.0000014042.54925.cc.

44. Smith L, Watson MB, O'Kane SL, Drew PJ, Lind MJ, Cawkwell L. The analysis of doxorubicin resistance in human breast cancer cells using antibody microarrays. Mol Cancer Ther. 2006;5(8):2115-20. doi: 10.1158/1535-7163.MCT-06-0190.

45. Nepomuceno JC. Lapachol and its derivatives as potential drugs for cancer treatment. iConcept Press Ltd. Retrieved from Res net/profile/Julio_Nepomuceno/publication/268378689_Lapachol_and_its_derivatives_as_poten tial_drugs_for_cancer_treatment/links/5469c8640cf20dedafd103e1 pdf. Published online 2014.

46. Brooks SC, Locke ER, Soule HD. Estrogen receptor in a human cell line (MCF-7) from breast 
carcinoma. J Biol Chem. 1973;248(17):6251-3. doi: 10.1016/S0021-9258(19)43537-0.

47. Lee A V, Oesterreich S, Davidson NE. MCF-7 cells-changing the course of breast cancer research and care for 45 years. JNCI J Nat/ Cancer Inst. 2015;107(7):1-4. doi: 10.1093/jnci/djv073.

48. Stein U, Jürchott K, Walther W, Bergmann S, Schlag PM, Royer H-D. Hyperthermia-induced nuclear translocation of transcription factor YB-1 leads to enhanced expression of multidrug resistancerelated ABC transporters. J Biol Chem. 2001;276(30):28562-9. doi: 10.1074/jbc.M100311200.

49. Zhou J, Duan $\mathrm{L}$, Chen $\mathrm{H}$, et al. Atovaquone derivatives as potent cytotoxic and apoptosis inducing agents. Bioorg Med Chem Lett. 2009;19(17):5091-4. doi: 10.1016/j.bmcl.2009.07.044.

50. Duffy R, Wade C, Chang R. Discovery of anticancer drugs from antimalarial natural products: a MEDLINE literature review. Drug Discov Today. 2012;17(17-18):942-53. doi: 10.1016/j.drudis.2012.03.013.

51. Nicoletti I, Migliorati G, Pagliacci MC, Grignani F, Riccardi C. A rapid and simple method for measuring thymocyte apoptosis by propidium iodide staining and flow cytometry. J Immunol Methods. 1991;139(2):271-9. doi: 10.1016/0022-1759(91)90198-O.

52. Lee Y. Cytotoxicity evaluation of essential oil and its component from Zingiber officinale Roscoe. Toxicol Res. 2016;32(3):225-30. doi: 10.5487/TR.2016.32.3.225.

53. Ju J-F, Banerjee $\mathrm{D}$, Lenz $\mathrm{H}-\mathrm{J}$, et al. Restoration of wild-type p53 activity in p53-null HL-60 cells confers multidrug sensitivity. Clin cancer Res. 1998;4(5):1315-22.

54. Durland-Busbice $S$, Reisman D. Lack of $p 53$ expression in human myeloid leukemias is not due to mutations in transcriptional regulatory regions of the gene. Leukemia. 2002;16(10):2165-7. doi: 10.1038/sj.leu.2402647.

55. Karpinich NO, Tafani M, Schneider T, Russo MA, Farber JL. The course of etoposide-induced apoptosis in Jurkat cells lacking p53 and Bax. J Cell Physiol. 2006;208(1):55-63. doi: 10.1002/jcp.20638.

56. Noh WC, Mondesire WH, Peng J, et al. Determinants of Rapamycin Sensitivity in Breast Cancer Cells. Clin Cancer Res. 2004;10(3):1013-23. doi: 10.1158/1078-0432.ccr-03-0043.

57. Kathryn JC, Sireesha V G, Stanley L. Triple Negative Breast Cancer Cell Lines: One Tool in the Search for Better Treatment of Triple Negative Breast Cancer. Breast Dis. 2012;32:35-48. doi:10.3233/BD2010-0307.

58. Borralho PM, Moreira da Silva IB, Aranha MM, et al. Inhibition of Fas expression by RNAi modulates 5-fluorouracil-induced apoptosis in HCT116 cells expressing wild-type p53. Biochim Biophys Acta - Mol Basis Dis. 2007;1772(1):40-7. doi:10.1016/j.bbadis.2006.09.005.

59. Yu X, Han B, Guo S, Hu B, Pan X, Li H. RITA has growth inhibitory activity on colon cancer HCT116 cells expressing wild-type $p 53$, but not SW480 cells harboring mutant $p 53$, via repressing wildtype p53 ubiquitination. Int J Clin Exp Med. 2016;9(9):17569-78.

60. Arif K, Hussain I, Rea C, El-Sheemy M. The role of Nanog expression in tamoxifen-resistant breast cancer cells. Onco Targets Ther. 2015;8:1327-34. doi:10.2147/OTT.S67835.

61. Baguley BC, Hicks KO, Wilson WR. Tumour cell cultures in drug development. Anticancer Drug Dev. Published online 2002:269-84.

62. Valença WO, Baiju T V., Brito FG, et al. Synthesis of Quinone-Based N-Sulfonyl-1,2,3-triazoles: 
Chemical Reactivity of $\mathrm{Rh}(\mathrm{II})$ Azavinyl Carbenes and Antitumor Activity. ChemistrySelect. 2017;2(16):4301-8. doi:10.1002/slct.201700885.

63. Souza-Fagundes EM, Queiroz ABR, Martins Filho OA, et al. Screening and fractionation of plant extracts with antiproliferative activity on human peripheral blood mononuclear cells. Mem Inst Oswaldo Cruz. 2002;97(8):1207-12. doi: 10.1590/S0074-02762002000800024.

64. Riss T, O'brien M, Moravec R. Choosing the right cell-based assay for your research. Cell notes. 2003;6(1):6.

65. Protopopova M, Hanrahan C, Nikonenko B, et al. Identification of a new antitubercular drug candidate, SQ109, from a combinatorial library of 1, 2-ethylenediamines. J Antimicrob Chemother. 2005;56(5):968-74. doi: 10.1093/jac/dki319.

66. Franken NAP, Rodermond HM, Stap J, Haveman J, Van Bree C. Clonogenic assay of cells in vitro. Nat Protoc. 2006;1(5):2315-9. doi: 10.1038/nprot.2006.339. 


\section{Supplementary Files}

This is a list of supplementary files associated with this preprint. Click to download.

- SupplementaryMaterialMCR.pdf 